\title{
Ortaöğretim Çağındaki Gençlerde Finansal Eğitimin Finansal Okuryazarlık Üzerindeki Etkisi
}

Doç. Dr. Şehnaz Bakır Yiğitbaş ${ }^{1 *}$ Dr. Öğr. Üyesi Erdem Temeloğlu ${ }^{2}$ Öğr. Gör. Adnan Şimşek ${ }^{3}$

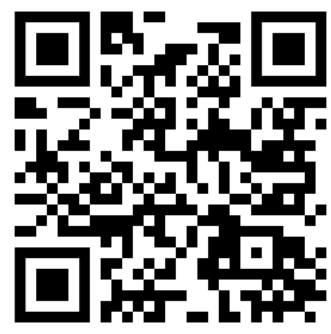

Geliş tarihi: 23.09 .2020

Kabul tarihi: 18.11.2020

\section{Atıf bilgisi:}

IBAD Sosyal Bilimler Dergisi

Sayı: Özel Sayı Sayfa: 411-432 Yıl: 2020

This article was checked by iThenticate. Similarity Index $20 \%$

Bu makalede araştırma ve yayın etiğine uyulmuştur.

${ }^{1}$ Çanakkale Onsekiz Mart Üniversitesi, Türkiye, sehnazbakir@comu.edu.tr, ORCID ID 0000-0002-5541-2462

2 Çanakkale Onsekiz Mart Üniversitesi, Türkiye, etemeloglu@,comu.edu.tr, ORCID ID 0000-0001-8572-9172

3 Çanakkale Onsekiz Mart Üniversitesi, Türkiye, adnansimsek@.comu.edu.tr, ORCID ID 0000-0002-5395-8656

* Sorumlu yazar
ÖZ

$\mathrm{Bu}$ araştırma Çanakkale ili Ayvacık ilçesindeki ortaokullarda eğitim gören gençlerde tasarruf bilinci oluşturmak ve gelecek dönemlerde tasarruflarını verimli alanlara yönlendirmelerini sağlamak amacıyla finansal okuryazarlık konusunda bir altyapı kazandırmayı amaçlanmaktadır. $\mathrm{Bu}$ amacı gerçekleştirmek için ortaöğretimde eğitim gören 12-14 yaş grubuna finansal eğitim verilmesi planlanmıştır. Projenin oluşturulması ve uygulanması aşamasındaki temel beklenti, ortaöğretim öğrencilerinin finansal konu ve sorunlara bakış açısının değişeceği ve onların gelecekteki finansal yönetim becerilerinin artmasına önemli katkı yapacağı yönündedir. Eğitim sonrasında gençlerin günlük basit harcamalara ilişkin daha rasyonel hareket etmesi, parasal işlemleri daha kolay yapması, ihtiyaçlar ve istekleri doğru bir şekilde ayırt etmesi, bilinçli tüketim yapması ve tasarruf farkındalığına erken yaşlarda ulaşması ve böylece ülke ekonomisine doğrudan ya da dolaylı katkı yapması beklenmektedir. Finansal eğitimin gençlerin finansal okuryazarlığı üzerindeki etkisi anket soruları ile ölçülmüştür. Nicel yönteme dayanan formel yapıdaki anket soruları hem finansal eğitim öncesi hem de finansal eğitim sonrası uygulanmıştır. Bu çalışmada, finansal eğitimin ortaöğretim düzeyindeki gençlerin finansal okuryazarlıkları üzerinde olumlu bir etki yarattığı bulgusuna ulaşılmıştır.

Anahtar kelimeler: Finansal Okuryazarlık, Tasarruf, Finansal Eğitim 


\title{
The Impact of Financial Literacy Education on Financial Literacy of Secondary School
}

\section{Students}

\author{
Assoc. Prof. Dr. Şehnaz Bakır Yiğitbaş ${ }^{*}$ \\ Assist. Prof. Dr. Erdem Temeloğlu ${ }^{2}$ \\ Lec. Adnan Şimşek ${ }^{3}$
}

First received: 23.09 .2020

Accepted: 18.11.2020

\section{Citation:}

IBAD Journal of Social Sciences

Issue: Special Issue Pages: 411-432

Year: 2020

This article was checked by iThenticate. Similarity Index 20\%

${ }^{1}$ Çanakkale Onsekiz Mart Üniversity,

Turkey, sehnazbakir@comu.edu.tr,

ORCID ID 0000-0002-5541-2462

2 Çanakkale Onsekiz Mart Üniversity, Turkey, etemeloglu@,comu.edu.tr, ORCID ID 0000-0001-8572-9172

3 Çanakkale Onsekiz Mart Üniversity, Turkey, adnansimsek@.comu.edu.tr, ORCID ID 0000-0002-5395-8656

* Corresponding Author

\begin{abstract}
This study aims to provide the foundation for financial literacy in order to raise awareness of savings among the students studying in secondary schools in Ayvac1k district of Çanakkale province and to enable them to direct their saving to productive areas in the future. For this purpose, financial education is planned for the 12-14 age group studying in secondary education. The main expectation during the creation and implementation phase of the project is that secondary school students' perspective on financial issues and problems will change, and it will make a significant contribution to their future financial management skills. After the training, the youth are expected to act more rationally regarding daily simple expenses, to make monetary transactions easier, to distinguish the needs and desires accurately, to make conscious consumption and to reach savings awareness at an early age and thus to contribute directly or indirectly to the national economy. The impact of financial education on the financial literacy of the young was measured with survey questions. The survey questions in a formal structure based on the quantitative method were applied both before and after financial education. In this study, it was found that financial education has a positive effect on the financial literacy of the youth at secondary education level.
\end{abstract}




\section{GİRIŞ}

Günümüzde sürdürülebilir kalkınma hedefini desteklemek amacıyla tasarruf bilincinin yükseltilmesi, birikimlerin arttırılması ve bunun içinde tabana yayılan bir finansal okuryazarlığın sağlanması önem kazanmaktadır. Atkinson ve Messy (2012) özellikle krediye bağımlılı̆̆ı azaltması açısından ekonomik birimlerin tasarruf davranışının finansal okuryazarlığın önemli bir bileşeni olduğunu belirtmektedir. Toplumda finansal okuryazarlığın artırılması finansal eğitimin yaygınlaştırılması ile mümkün olabilecektir. Finansal eğitim almış bireylerin iktisadi konulardaki davranış biçimiyle ülke ekonomisine önemli faydalar sağladığı bilinen bir gerçektir.

Finansal okuryazarlık kavramı, literatürde çok çeşitli tanımlara konu olmakla birlikte, en yalın haliyle Noctor ve diğerleri (1992)'nın vermiş olduğu tanımı benimseyebiliriz. Buna göre, finansal okuryazarlık, bireylerin paranın yönetilmesine ve kullanılmasına dair bilinçli değerlendirmeler yapabilme ve etkili kararlar alabilme becerisidir. Finansal okuryazarlıkla ilgili iki temel unsurun ön plana çıktığı söylenebilir; bunlardan ilki, bireylerin mali kaynaklarını etkili bir biçimde yönetebilecek bilgi ve beceriye sahip olması, ikincisi ise bu bilgi ve beceriyi kullanma kabiliyetidir. $\mathrm{Bu}$ ise finansal kavramlar, ürünler ve hizmetler konusunda bilgi sahibi olmayı gerektirir.

Bir toplumda finansal okuryazarlık düzeyinin artması ancak finansal eğitimin yaygınlaştırılması ile sağlanacaktır. Bu açıdan, finansal okuryazarlık, finansal alanda bilgili tüketicilerin yetiştirilmesi için bir amaç, finansal eğitim ise bu amaca ulaşmayı sağlayan bir araçtır (Goel ve Khanna, 2013). Finansal eğitim; tüketicilerin ve yatırımcıların finansal ürün, hizmetler ve kavramlar hakkında öğretme yoluyla bilgi sahibi olmaları, finansal riskler ve firsatlara ilişkin farkındalıklarının artması, kararlarını kendi çıkarlarını gözeterek alma ve bunu uygulamada bir güven oluşturma sürecidir (OECD, 2008, Goel ve Khanna, 2013).

Finansal eğitimin önemi, bireylerin finansal okuryazarlık düzeylerini artırmasında yatmaktadır. Nitekim finansal okuryazarlık seviyesi düşük olan bireylerde ödeme gücüne göre borçlanma, düşük maliyetli olarak borçlanma ve borçları zamanında ödeme konusunda olumsuz davranışlar daha yaygındır (Hastings ve diğerleri, 2012). Oysa, finansal okuryazarlık seviyesi yüksek bireyler, borç ödeme kapasitelerini daha iyi belirleyebilmekte ve bütçelerine uygun borçlanma kararları alabilmektedirler (Lusardi ve Tufano, 2009). Diğer taraftan, finansal okuryazarlığın geliştirilmesi, bireylerin tasarruf davranışını pozitif yönde etkilemektedir (OECD, 2014). Finansal okuryazarlık seviyesi yüksek olan bireylerin tasarruf araçları konusunda daha fazla bilgi sahibi olmaları tasarruf eğilimlerini etkileyecektir. OECD (2005) tasarruf eksikliğinin finansal bilgi ve beceri eksikliğinden kaynaklanması durumunda, bunun finansal eğitim ile aş1labileceğini belirtmektedir.

O halde bir toplumda finansal okuryazarlık düzeyinin artırılması için etkin finansal eğitim programlarının oluşturulması gerekmektedir. Finansal eğitim alacak hedef kitle için ilk olarak finansal okuryazarlık seviyesinin ölçülmesi, sağlıklı bir ölçüm yapılabilmesi için de finansal okuryazarlık tanımının ve çerçevesinin iyi belirlenmesi, objektif ve güvenilir göstergelerle ölçülmesi gerekmektedir. Birçok ülkede, finansal okuryazarlık seviyelerini ölçmeye yönelik hem kamu ve özel sektör, hem de uluslararası kuruluşlar tarafindan anketler yapılmış ve bu anketlerde genel olarak finansal okuryazarlık seviyesinin düşük olduğu belirlenmiştir. Bireylerin finansal kararlar almada yeterli beceri düzeyine sahip olmadıkları, tasarruf ve yatırıma ilişkin kavramlara yeterince hâkim olmadıkları bu anketlerde tespit edilmiştir. (Lewis ve Messy, 2012). Bu nedenle, birçok Avrupa ülkesinde, toplumda finansal okuryazarlık performansını artırmaya yönelik önemli çalışma, uygulama ve kampanyalar başlatılmıştır.

Uluslar arası kuruluşlar tarafından yapılan anketlerde, daha düşük gelir seviyesine sahip olan ülkelerde finansal okuryazarlık düzeyinin yüksek gelirli ülkelere göre daha düşük olduğunu ortaya koymuştur. $\mathrm{Bu}$ anketler içerisinde Türkiye'nin finansal okuryazarlık sıralaması dikkat çekmektedir. Örneğin International Network on Financial Education (OECD/INFE)'nin 12 Ekim 2016 tarihinde yayınlamış olduğu "Yetişkin Finansal Okuryazarlık Yetkinlik Anketi", 17'si OECD üyesi olmak üzere toplam 30 ülkede gerçekleştirilmiş ve Türkiye finansal bilgi, finansal davranış ve finansal tutum düzeyi genel ortalama skorunda ankete katılan 30 ülke arasında 21. sırada, ankete katılan 17 OECD üyesi ülke arasında da 15. sırada yer almıştır. Bu anket sonucu Türkiye'de finansal okuryazarlık seviyesinin artırılması ve finansal eğitimlerin yaygınlaştırılması gerekliliğini ortaya koymaktadır. 
Dünya genelinde hem genel bir kamuoyuna ulaşmayı hem de belirli hedef gruplarına yönelik bir çok finansal eğitim programları uygulanmaktadır. Ancak, finansal alışkanlıkların erken yaşlarda şekillendiği göz önüne alınacak olursa, erken yaşta verilen finansal eğitim, finansal okuryazarlığın temelini oluşturmada iyi bir firsat yaratmış olacaktır (OECD, 2014). Hem erken yaşlarda finansal farkındalık ve tasarruf bilincinin artırılması hem de gençlerin ailelerine kıyasla daha çok finansal riskle ve karmaşık finansal araçla karşılaşmaları, gençler için verilecek finansal eğitimin önemini artırmaktadır. Özellikle Türkiye gibi, gençlerin nüfus içerisindeki göreli payının yüksek olduğu ülkelerde gençler için finansal eğitimin önemi bir kat daha artmaktadır. Gençlerin çalışma yaşamına atılmadan önce ilk gençlik dönemlerinde bütçeleme ve tasarruf etme, masraflarını ve borçlarını kontrol altına alma gibi konularda bilinçli olmalarını sağlayacak finansal eğitim programlarının oluşturulması gerekmektedir. Daha erken yaşlarda öğrenilen ve uygulanan finansal davranışlar daha kalıcı olarak yaşamın sonraki aşamalarında bireylerin finansal davranışlarının belirleyicisi olabilecektir. $\mathrm{Bu}$ ise bireysel ve toplumsal refahın artmasına, ülke ekonomisinin sağlıklı gelişmesine tabandan/temelden katkı sağlayacaktır.

$\mathrm{Bu}$ araştırmada, toplumda finansal okuryazarlık seviyesinin artırılmasına katkı sağlamak amacıyla üniversite destekli araştırma projeleri kapsamında özellikle finansal eğitimin henüz yaygınlaştırılamadığı ilçelerde/kasabalarda gençlere finansal eğitim verilmesi ve eğitim sonrasında gençlerin finansal okuryazarlık düzeylerinin artıılması ve ölçülmesi amaçlanmaktadır. Bu araştırmada, her konuda olduğu gibi finansal okuryazarlık eğitiminin de en azından ortaöğretim çağından itibaren verilmeye başlanması düşüncesinden hareket edilmiştir. Projenin amac1, ilk gençlik dönemini temsil eden ortaokul çağındaki gençlerin mali varlıklarını yönetme davranışlarını olumlu yönde etkilemek, tasarruf yapma alışkanlıklarını özendirmek ve toplumun sağlıklı bir finansal yapıya kavuşturulmasını sağlamaktır. Finansal eğitim alacak kitle olarak, Çanakkale ili Ayvacık ilçesindeki ortaokullarda eğitim gören ve ilk gençlik dönemini temsil eden 12-14 yaş genç grubu seçilmiştir. Finansal eğitim Ayvacık ilçesi merkezinde yer alan, 7. ve 8 . sinıflarda eğitim gören ortaöğretimdeki toplam 320 öğrenciye verilmiştir.

Hedef kitle olarak seçilen gençlerin finansal okuryazarlık seviyelerini artırmak için belirli bir program çerçevesinde hareket edilmiştir. İlk olarak finansal okuryazarlık literatürü kapsamlı bir şekilde araştırılmış, incelenmiş ve finansal okuryazarlık düzeyini ölçebilecek göstergeler belirlenmiştir. Bu göstergelerin, 1214 yaş grubunda yer alan gençlerin finansal okuryazarlık düzeylerini ölçebilecek nitelikte olmasına özen gösterilmiştir. Araştırmada bilgi toplama yöntem ve aracı olarak formel yapıda düzenlenmiş ve belirli sayıda soru içeren "nicel yöntem"e göre hazırlanmış bir anket formu kullanılmıştır. Anket formunda yer alan sorularla öğrencilerin, para ve bankaların rolü, tasarruf, faiz, bütçe, harcamalar, istek ve ihtiyaçlar vb. temel kavramlar ile tasarruf anlayışına sahip olup olmadığı konusunda seviyeleri belirlenmiştir.

İkinci aşamada ölçülen değerlere uygun düzeyde bir finansal okuryazarlık eğitimi verilmiş ve ardından elde edilen sonuçlar çerçevesinde bir değerlendirme yapılmıştır. Finansal okuryazarlık eğitimi başta proje yürütücüsü ve iki öğretim elemanı araştırmacı olmak üzere, Ayvacık Meslek Yüksekokulu öğrencilerinin araştırmaya dahil edilmesiyle gerçekleştirilmiştir. Erişilmek istenilen amaç, ortaöğretim öğrencilerinin konu hakkında seviyelerini öğrenip, finansal eğitim sonrasında öğrencileri finansal terimler ve konular hakkında bilinçlendirmek ve eğilimlerini arttırmaya yönelik öneriler geliştirmektir. Bu amaca bağlı olarak, finansal eğitimde, ekonominin nasıl bir düzen içerisinde işlediği, bireyin finansal tutum ve davranışlarının toplumsal fayda ve zarara nasıl yol açacağı ve toplum olarak yaşam standartlarımızı yükseltmek için nasıl bir sorumluluk bilinci ile hareket etmemiz gerektiği felsefesinden hareketle, bu bilinci aşılayacak temel bilgiler verilmiştir. Finansal eğitim sonrası temel beklenti, ortaöğretim öğrencilerinin finansal konu ve sorunlara bakış açısının değişeceği ve gelecekteki finansal yönetim becerilerinin artmasına önemli katkı yapacağ 1 yönündedir. Bu beceri düzeyine ulaşan gençlerin günlük basit harcamalara ilişkin daha rasyonel hareket etmesi, parasal işlemleri daha kolay yapması, bilinçli bir tüketim yapması, ihtiyaçlar ve istekleri doğru bir şekilde ayırt edebilmesi ve bir tasarruf bilinci farkındalığına erken yaşlarda ulaşması böylece ülke ekonomisine doğrudan ya da dolaylı katkı yapması projeden beklenen sonuçtur.

Üçüncü aşamada, hem finansal eğitim öncesi ve hem de finansal eğitim sonrası uygulanan anketlerden elde edilen veriler değerlendirilmiştir ve finansal eğitimin gençlerin finansal okuryazarlığı üzerinde etkisi tespit edilmiştir. Finansal eğitim sonrası, öğrencilere uygulanan anket aracıllğıyla eğitimin fayda düzeyi belirlenmiştir. Çünkü, projenin amacı finansal kavram ve anlayışa yeterli düzeyde sahip olmayan gençlerin finansal bir eğitim sürecinden geçirilerek, eğitim sonrasında gençlere finansal kavramları anlama ve 
finansal ürünleri doğru kullanma ve bütçelerini yönetme becerilerini geliştirmekti. Haklarını bilen, ekonomik faaliyetlere üretken bireyler olarak katılan, finansal araç ve ürünleri kendi yararına kullanma becerisi geliştiren kişilerin hem kendisinin, hem çevresinin refahını arttırması ve hem de sağlıklı bir ekonominin gelişimi için gerekli temel alt yapının oluşumuna katkıda bulunması arzulanmıştır. Bu son aşamada, bu hedeflere ne ölçüde ulaşıldığı değerlendirilmiştir.

Proje kapsamında gerçekleştirilen bu araştırma, kırsal bölgelerde/ilçelerde yaşayan gençlerin finansal bir eğitimle -yapılan ön araştırmalardan da görüldüğü gibi- ilk kez buluşacak olması ve meslek yüksekokullarının finans ve bankacılık bölümlerinin bu konuda sosyal bir sorumluluk projesi üstlenmesi ile finansal farkındalık yaratacak olması açısından özgün bir çalışma olmayı hedeflemiştir. Projede bankacılık ve sigortacılık programında eğitim gören öğrencilerin ilk etapta eğitimci olarak yetiştirilip daha sonra edindikleri bu bilgileri ortaöğretimdeki öğrencilere aktarmaları, onların araştırma bilincinin gelişmesine katkı sağlayacaktır. Bu çalışmanın hem bu boyutu hem de ortaöğretim çağındaki öğrencilerin finansal eğitim almaları ile aynı çevredeki öğretmen ve ebeveynler üzerinde yaratacağı dolaylı etki de dikkate alınacak olursa projenin yaygın etkisinin yüksek olacağı anlaşılabilir.

\section{LITERATÜR TARAMASI}

Finansal okuryazarlık üzerine yapılan ilk çalışmaların, 1990'lı yılların sonu ve 2000'li yılların başında, $\mathrm{ABD}$ ve İngiltere gibi finansal sistemin gelişmiş olduğu ülkelerde ortaya çıktığı görülmektedir. $\mathrm{Bu}$ çalışmalarda finansal okuryazarlı̆̆ın demografik değişkenler (cinsiyet, eğitim düzeyi, gelir, yaş grubu) açısından durumu ve tasarruf/para yönetimi gibi diğer değişkenler üzerindeki etkileri araştırılmaktadır. Araştırmaların özellikle üniversite öğrencileri üzerine yoğunlaştığı ve bireylerin finansal okuryazarlık düzeyinin düşük olduğu yönünde tespitler yapıldığı görülmektedir. Örneğin, Chen ve Volpe (1998) 924 üniversite öğrencisi üzerinde yaptıkları çalışmalarında öğrencilerin finansal okuryazarlık seviyelerini, finansal okuryazarlık ve öğrencilerinin karakteristikleri arasındaki ilişkiyi ve finansal okuryazarlığın öğrencilerin düşüncelerine ve kararlarına olan etkisini araştırılmışlar, üniversite öğrencilerin kişisel finans hakkında bilgili olmadıkları ve bu nedenle bilgiye dayalı karar almada sorunlar yaşayabileceklerini belirtmişlerdir. Beal ve Delpachitra (2003), Avustralya'daki Southern Queensland Üniversitesi'nde (USQ) eğitim gören ve 789 öğrencinin katıldığı anket çalışması ile üniversite öğrencilerinin finansal okuryazarlık düzeylerini lojistik regresyon modeli kullanarak incelemişler ve üniversite öğrencilerinin finansal okuryazarlık düzeylerinin düşük olduğu bulgusuna ulaşmışlardır. Lusardi (2008) çalışmasında Amerika Birleşik Devletleri'nde düşük seviye finansal okuryazarlığın yaygın olduğu, düşük eğitim düzeyine sahip bireylerde finansal okuryazarlığın daha düşük seviyelerde olduğunu, finansal okuryazarlık seviyesi düşük bireylerin daha az tasarrufta bulunduğunu tespit etmiştir.

Bireylerde finansal okuryazarlık seviyesini aile yapıları ile ilişkilendiren çalışmalar bulunmaktadır. Örneğin, Cude ve diğerleri (2006) öğrencilerin finansal bilgi davranışlarını nasıl edindikleri ve risk üstlenme derecelerini etkileyen faktörleri incelemişlerdir. Bu araştırma University Of Georgia (UGA)'dan 491, Luisiana State University (LSU)'dan 1400 öğrenci olmak üzere, toplam 1891 öğrencinin anket çalışmasına katılımı ile gerçekleştirilmiştir. Araştırma sonucuna göre hem risk hem finansal okuryazarlık düzeyinin aileden öğrenildiği ve ailenin çocukların finansal sosyalleşmelerinde kilit rol oynadığı belirlenmiştir. Lusardi, Mitchell ve Curto (2010) gençler arasında yaptıkları finansal okuryazarlık araştırmasında, finansal okuryazarlık seviyesinin düşük olduğunu; genç yetişkinlerin üçte birinden daha azının faiz, enflasyon, risk dağıtımı gibi temel kavramları bildiğini saptamışlardır. Ayrıca, finansal okuryazarlığın sosyo-demografik özellikler ve aile finansal bilgi düzeyi ile ilgili olduğu görülmüştür. Murphy (2005), işletme okuyanların okumayanlara göre ve eğitimli ailelerin eğitimsiz ailelere göre daha yüksek bir finansal okuryazarlık seviyesine sahip olduğunu tespit etmiştir.

Finansal okuryazarlıkta cinsiyetin etkisi üzerine birçok araştırma yapılmış ve yapılan araştırmalarda genel olarak erkeklerin kadınlardan, daha yüksek başarı gösterdikleri görülmüştür (Worthington, 2006; Mandell,2008; Almenberg ve Save-Söderbergh, 2011). Wagland ve Taylor (2009) ise cinsiyet faktörünün finansal okuryazarlık üzerinde önemli bir etkisinin olmadığını belirtmişlerdir. Bazı çalışmalarda refah seviyesinin finansal okuryazarlık üzerinde pozitif etkiye sahip olduğu gösterilmiştir. Örneğin, Delavande ve diğerleri (2008) refah seviyesinin finansal okuryazarlık üzerinde pozitif etki yarattığını tespit etmişlerdir. 
Jappelli ve Padula (2011) 39 ülkeyi karşılaştırmalı olarak analiz etmiş ve finansal okuryazarlığın, ulusal tasarruflar konusunda güçlü bir belirleyici faktör olduğunu keşfetmiş ve finansal okuryazarlığın ulusal tasarruf seviyesini direkt etkileyen faktörlerden biri olduğunu bulmuştur. Bu çalışmaya göre, genel finansal okuryazarlık skorunun standart sapmasındaki bir seviyelik artış ulusal tasarrufun \% 3,6 artırdığını tespit etmiştir. Lusardi, Michaud, ve Mitchell (2013), çalışma kariyerlerinin erken aşamalarında finansal eğitim alan gençlerin, hayatlarının geri kalanında daha fazla finansal kazanç elde ettiklerini göstermiştir. Worthington (2006), Avustralya'da yaşayan yetişkin insanların finansal okuryazarlıklarını incelemişler, finansal okuryazarlık düzeyi en yüksek olan kişilerin 50-60 yaş aralığındaki, profesyoneller, işyeri veya çiftlik sahipleri ile üniversite öğrencileri olduğunu tespit etmiş̧lerdir. Finansal okuryazarlık düzeyi en düşük olan grup ise; işsizler, kadınlar ve düşük eğitim seviyesine sahip olan katılımcılardır.

Finansal eğitimin finansal okuryazarlık üzerinde pozitif bir etkisinin olduğu yönündeki düşüncenin aksine Mandell ve Klein (2007) genç yetişkinlerin, bireysel finans hakkında kurs görmelerine rağmen düşük finansal okuryazarlık puanına sahip olduğunu tespit etmişler ve bunun nedenini bireylerin öğrenmeye ve yeteneklerinin geliştirmeye karşı olan motivasyon eksikliğinden kaynaklandığ 1 hipotezine dayandırmışlardır. 1997, 2000, 2002, 2004 ve 2006 yıllarında lise son sınıf öğrencilerine anketler uygulanmıştır. Elde edilen sonuçlara göre, yıllar geçtikçe, anket sonuçları daha düşük yüzdelere sahip olmaktadır. Yani, Amerika'da lise son sınıf öğrencilerinin finansal okuryazarlık seviyeleri düşmektedir. Para yönetimi ve bireysel finans ile ilgili verilen derslerin, öğrencilerin finansal bilgisizliklerini gideremediği ve bu doğrultuda motivasyon eksikliği olduğu saptanmıştır.

Gelişmekte olan ülkelerde finansal okuryazarlığın önemi konusunda genellikle bir fikir birliği ön plana çıkmakla birlikte gelişmekte olan ülkelerdeki çalışmaların oldukça sınırlı olduğu görülmektedir (Wagland ve Taylor, 2009). Ancak, son yillarda gelişmekte olan ülkelerde de finansal okuryazarlık üzerine çalışmaların arttığı görülmektedir. Bu çalışmalardan bazıları şunlardır; Sabri ve Mac Donald (2010) Malezya'daki üniversite öğrencilerinin finansal okuryazarlıkları ile tasarruf davranışları arasındaki ilişki incelemek amacıyla Malezya'daki 11 üniversiteden 2519 öğrenciye anket uygulanmışlar ve finansal okuryazarlık ile tasarruf davranışları arasında pozitif bir ilişki olduğunu tespit etmişlerdir. Krizek ve Hradil (2012) Çek Cumhuriyeti'nde tesadüfi olarak seçilen 2120 üniversite öğrencisine online anket uygulamışlar ve erkeklerin finansal okuryazarlık düzeyinin kadınlara göre daha yüksek olduğu bulgusuna ulaşmışlardır. Nidar ve Bestari (2012) araştırmalarında, Endonezya'daki üniversite öğrencilerine uyguladıkları anket sonucunda öğrencilerin finansal okuryazarlık düzeylerini etkileyen faktörlerin; eğitim düzeyi, fakülte, gelir düzeyi, aileden edinilen bilginin etkili olduğu sonucuna ulaşmışlardır.

Türkiye'de ise finansal okuryazarlık konusuna son ylllara kadar yeterli önemin verilmediği görülmektedir. Finansal okuryazarlık ölçümünde davranışların etkilerinin belirlenmesi amacıyla OECD INFE (2012) araştırması anketi çeşitli sorularla dikkatli alışveriş, bütçeleme, tasarruf ve yatırım gibi davranışlar hakkında bilgi edinmeye amaçlamıştır. Araştırmaya katılanlardan İngiliz Virgin Adası katılımcıları en yüksek finansal davranış puanını alırken, Türkiye sondan ikinci sırada ancak yerini alabilmiştir.

Türkiye'de finansal okuryazarlık üzerine yapılan araştırmalara bakıldığında son yıllarda bu konudaki çalışmaların arttığı görülmektedir. Bu çalışmalardan bazıları şunlardır: Er ve diğerleri (2017), lise öğrencilerinin, Sarıgül (2014), Şahin (2014) meslek yüksekokulu öğrencilerinin, Bayram (2015), Alkaya ve Yağlı (2015), Kılıç ve diğerleri (2015), Şamiloğlu ve diğerleri (2016), Sezer ve Gümüş (2016), Tuna ve Ulu (2016), Kocabıyık ve Teker (2018) lisans öğrencilerinin finansal okuryazarlık düzeyinin tespitine yönelik olarak çalışmışlardır. Bu çalışmalar büyük oranda benzer sonuçlara ulaşmışlardır. Örneğin, Er ve diğerleri (2017) eğitim alanları ile finansal bilgi düzeyi arasında anlamlı bir ilişki olduğu, ekonomi ve finans alanında alınan ders sayısı ve ders çeşitliliğinin finansal okuryazarlık düzeyini etkilediği ve cinsiyetin de finansal okuryazarlık düzeyini etkileyen bir faktör olduğu sonucuna ulaşmışlardır. Sarıgül (2014), 3 farklı üniversiteden 1127 öğrenciye yaptıkları anketlerle eğitim bilimleri ve sağlık bilimleri öğrencilerinin diğerlerinden daha düşük finansal okuryazarlığa sahip olduğunu tespit etmişlerdir. Kılıç ve diğerleri (2015) erkeklerin kadınlara oranla, İktisadi ve İdari Bilimler Fakültesi öğrencilerinin diğer tüm fakülte öğrencilerine oranla daha yüksek finansal okuryazarlık düzeyine sahip oldukları sonucuna yaptıkları anketlerle ulaşmışlardır. Şamiloğlu ve diğerleri (2016), işletme öğrencilerinin diğer öğrencilere göre daha yüksek finansal okuryazarlık bilgisine sahip olduğunu tespit etmişlerdir. Bu araştırmalar finansal

IBAD Sosyal Bilimler Dergisi / IBAD Journal of Social Sciences, (Özel Sayı/Special Issue), 2020 
eğitimin önemini vurgulamakla birlikte, finansal okuryazarlık üzerine üniversite öğrencilerine yönelik olarak yapılan anket çalışması ve bunun sonuçlarını yayınlamak şeklinde ortak bir niteliğe sahiptirler.

Finansal okuryazarlığın geliştirilmesi yönünde Türkiye'deki uygulamalara ${ }^{1}$ baktığımızda hem resmi hem de sivil toplum kuruluşları tarafından finansal okuryazarlığın toplumda yaygınlaştırılması yönünde önemli adımların atıldığı ve finansal eğitim politikalarının belirlendiği görülmektedir. Bu konudaki ilk adım 3 Haziran 2011 tarihinde Finansal İstikrar Komitesi'nin kurulmasıdır. Komite, Hazine Müsteşarlığının bağlı olduğu Bakanın başkanlığında, Hazine Müsteşarı ile TCMB, BDDK, SPK ve TMSF başkanlarından oluşmaktadır. Finansal İstikrar Komitesi tarafından hazırlanan "Finansal Erişim, Finansal Eğitim, Finansal Tüketicinin Korunması Stratejisi ve Eylem Planları"na ilişkin 2014/10 sayılı Başbakanlık Genelgesi 5 Haziran 2014 tarihinde Resmi Gazete'de yayımlanmıştır. Strateji ve Eylem Planı kapsamında, ailelere finans konusunda eğitimler verilmesi, ev hanımlarının, çalışmayan gençlerin, yaşlıların vs. finansal konularda bilgilendirilmesi hedeflenmiştir.

Aile ve Sosyal Politikalar Bakanlığı, Finansal Okuryazarlık ve Erişim Derneği (FODER) ile imzaladığı iş birliği protokolü çerçevesinde, 14-25 yaş grubu çocuk ve gençlere bilinçli harcama, mevcut kaynaklarını etkin kullanma ve tasarruf konusuna ilişkin finansal okuryazarlık ve farkındalık eğitimleri düzenlemektedir. Milli Eğitim Bakanlığı Mesleki ve Teknik Eğitim Genel Müdürlüğünün 2016 yılında TEB ile imzalamış olduğu Finansal Okuryazarlık İş Birliği Protokolü çerçevesinde bütçeleme, tasarruf etme, yatırım yapma, borçlanma ile finansal hak ve yükümlülükler konusunda öğretmen ve öğrencilerin finansal farkındalık ve bilinç düzeylerini artırmaya yönelik seminerler düzenleneceği belirtilmiştir.

2015 yılında yayımlanan Onuncu Kalkınma Planında "Öncelikli Dönüşüm Programı” nda yer alan "Yurtiçi Tasarrufların Arttırılması ve İsrafın Önlenmesi Programı" çerçevesinde belirlenen ilk politika "Finansal farkındalığın artırılması ve finansal eğitimin yaygınlaştırılması"dır. SPK sorumluluğunda yürütülecek bu eylemde ülkemizdeki finansal okuryazarlık düzeyinin izlenmesine yönelik periyodik aralıklarla anket çalışmaları yapılması, finans konusunda eğitim ve tanıtım materyalleri ile eğitici görseller oluşturulması, konferans, seminer, TV-radyo programları ve yarışmalar yoluyla finansal konulara ilginin artırılması, aile fertleri ve kadınların, öğretmenler ile eğitim yöneticilerinin, kamu ve özel sektörde işe yeni başlayanların finansal farkındalıklarının ve finansal okuryazarlık seviyelerinin artırılmasına yönelik çalışmalar yapılacağı belirtilmiştir. İlk ve orta öğretim düzeyinde müfredattaki ve yaygın eğitim programlarındaki temel finans konularının geliştirilmesine de yer verilmiştir.

Finansal okuryazarlık ve erişim amaçlı olarak kurulan, OECD tarafindan akredite edilmiş Türkiye'deki ilk ve tek sivil toplum kuruluşu FODER ise 2012 yılından itibaren gençler, ilköğretim öğrencileri, girişimciler, askerler, kadınlar vb. farklı hedef kitlelerin finansal farkındalıklarını artırmayı ve finansal okuryazarlık seviyelerine katkı sağlamayı amaçlamaktadır. Doğuş Grubu'nun “3 Kumbara Finansal Okuryazarlık Eğitimi Programı" çocukları finansal konularda bilinçlendirmeyi amaçlamaktadır. Program kapsamında dördüncü sınıf öğrencilerinin "hedeflerini plana dönüştürebilmeleri, istek, ihtiyaç, birikim, tasarruf, gelir, gider ve paylaşım gibi kavramları öğrenmeleri ve bütçe yapabilmelerine yönelik farkındalık ve bilgilendirme faaliyetleri düzenlenmektedir. Bu kapsamda, çocukların harçlıklarını iyi yönetebilmeleri ve para konusunda doğru alışkanlıklar edinebilmeleri için birikim, paylaşım ve harcama kumbaralarıyla yeni bir uygulama başlatılmıştır. Program kapsamında Milli Eğitim Bakanlığı ile birlikte belirlenen illerde ilkokul 4. sınıf öğrencilerine sınıf içi eğitimler verilmekte, Milli Eğitim Bakanlığı ve Doğuş Grubu iş birliğiyle 2017 yılı sonuna kadar 81 ilde yarım milyon öğrenciye ulaşılması hedeflenmektedir.

Kalkınma Bakanlığı, Birleşmiş Milletler Kalkınma Programı Habitat Kalkınma ve Yönetişim Derneği, Visa Europe Türkiye ve üye bankalarının katılımıyla 2009 yılında başlatılan "Paramı Yönetebiliyorum Projesi", ülkemizde 15-30 yaş arası gençlerin kişisel mali kaynaklarını bütçelemelerine ve finansal hizmetleri doğru kullanmalarına destek olacak bir eğitim imkânı sunmaktadır. Ülke genelinde finansal okuryazarlık alanında farkındalık oluşturmak amacıyla TEB'in kurmuş olduğu TEB Aile Akademisi ise bütçe oluşturma ve yönetimi, aile giderlerini kontrol altında tutma taktikleri, borçların doğru yönetimi, yatırım yaparken dikkat edilmesi gereken hususlar, bireysel emeklilik, kredi ve kredi kartlarının doğru kullanımı gibi konularda eğitimci sertifikasına sahip şube müdürleri ve gönüllü TEB çalışanları tarafından birebir ve ücretsiz finansal eğitim hizmeti vermektedir. ING'nin tasarruf davranışlarını etkilemek amacıyla

\footnotetext{
${ }^{1}$ Bkz. Çiğdem Karataş. (2017).
} 
kurmuş olduğu "Turuncu Damla Programı” 3. ve 4. sınıf öğrencilerine yönelik olarak finansal okuryazarlık eğitimleri vermektedir.

Özetle, Türkiye'de hem resmi kuruluşlar ve finans kuruluşları hem de sivil toplum örgütleri tarafindan finansal okuyazarlık seferberliğinin başlatıldığı söylenebilir. "Ortaöğretim Çağındaki Gençlerde Finansal Okuryazarlık ve Tasarruf Bilincinin Geliştirilmesi" adlı üniversite projesi çerçevesinde gerçekleştirilen bu araştırma ise, bu seferberliği destekleyici ve tamamlayıcı nitelikte olup, gençliğin ilk başlangıç döneminde olan ve finansal eğitim alma imkanına henüz sahip olmamış ve kırsal bölgelerde eğitim gören 12-14 yaş grubu ortaöğretim öğrencilerine finansal eğitim verilmesini hedeflemiştir. Gençlerin finansal bilgi, tutum ve davranışlarını yönlendirmek amacıyla öğrencilere finansal eğitim verilmiş ve finansal eğitimin ögrencilerin finansal okuryazarlıklarına etkisi belirlenmiştir.

\section{YÖNTEM}

\section{Araştırmanın Amacı, Hipotezi ve Kitlesi}

Araştırmada, ortaöğretim çağındaki öğrencilerin finansal okuryazarlık düzeylerinin belirlenmesi, tasarruf davranışlarının analiz edilmesi ve finansal eğitimin öğrencilerin finansal okuryazarlık düzeyine etkisinin incelenmesi hedeflenmiştir. Finansal okuryazarlık eğitimle yakından ilgilidir ve eğitim düzeyi yüksek olanların finansal okuryazarlık düzeyi ile ilgili sorulara verdiği cevapların doğruluk oranın da yükseleceği beklenmektedir (Sekita, 2011). Finansal beceriye sahip olma herhangi bir bilgi donanımı olmadan ve bu bilgiyi kullanmasını bilmeden mümkün değildir. Bu bağlamda, araştırma, finansal eğitim düzeyi arttıkça finansal okuryazarlık seviyesinin de artacağı temel hipotezine dayanmaktadır. Ayrıca, öğrencilerin finansal okuryazarlık düzeyinin cinsiyet, gelir düzeyi, ailenin eğitim düzeyi gibi demografik özelliklerle olan ilişkisi de araştırılmış ve öğrencilerin demografik özelliklerine göre finansal okuryazarlık düzeyinin farklılaşıp farklılaşmadığı test edilmiştir.

Araştırmanın hedef kitlesini Çanakkale'nin Ayvacık ilçesi merkezinde yer alan 7. ve 8. sınıf ortaokullarında eğitim gören öğrenciler oluşturmaktadır. İlk gençlik dönemi olan 12-14 yaş genç grubunun hedef kitle olarak belirlenmesi nedeniyle ortaöğretimde eğitim gören 7. ve 8. sinıf öğrencileri seçilmiştir. Bu kapsamda, Ayvacık ilçesinde yer alan üç ortaokulun (Atatürk Ortaokulu, Ümmühan Ortaokulu ve İmam Hatip Ortaokulu) 7. ve 8. sınıf öğrencinin toplam sayısı olan 320 öğrenci, araştırmanın örneklemini oluşturmaktadır.

\section{Verilerin Toplanması ve Analizi}

Araştırmada veri toplama yöntemi olarak nicel araştırma yöntemlerinden anket tekniğinden yararlanılmıştır. Bu konuda araştırma boyunca izlenen strateji; birinci aşamada finansal okuryazarlık literatürünün incelenerek "finansal okuryazarlık" seviyesini ölçen doğru anket sorularını oluşturmak, her bir öğrenciye uygulanacak anket sorularının yüzyüze uygulamasını sağlamaktır. Anket soruları hazırlanırken öğrencilerin tasarruf bilinci ve tasarruf davranışı, temel bankacılık bilgisi, faiz hesaplamaları, temel ekonomi bilgileri ve günlük basit hesaplamalara dayalı bilgilerini ölçebilecek düzeyde olmasına özen gösterilmiştir ve "Etik Kurul" izni Çanakkale Üniversitesi Sosyal Bilimler ve Eğitim Bilimleri Etik Kurulu 26.08.2019 tarih 6 nolu toplantı 2019/46 sayısı ile alınmış 40 sorudan oluşan bir anket hazırlanmıştır.

Finansal okuryazarlık düzeyinin ölçülmesinde belirli bir standart bulunmamakla birlikte temel bazı göstergelerden yararlanılmaktadır. Bu konuda kullanılan bazı göstergeler bazen temel ekonomi terimlerini bilmekle (Hilgert, Hogarth ve Beverley, 2003) bazen de günlük parasal hesaplamaları ya da faiz hesaplamalarını yapabilmek ya da bileşik faiz, nominal ve reel getiri arasındaki farklılıklar ve risk çeşitlendirmesi gibi temel finansal kavramlara ait bilgi ile ilişkilendirilmektedir (Lusardi, 2008). Dolayısıyla, finansal okuryazarlık için farklı göstergelerin kullanılıyor olması, finansal okuryazarlıktan ne anlaşılması gerektiği ile ilgili nasıl bir tanım verdiğiniz ile doğrudan ilintili olabilmektedir. Örneğin Mandell (2006) finansal okuryazarlığı yeni ve karmaşık finansal enstrümanlar arasında değerlendirme yeteneğine sahip olmak ve bilgiye dayalı kararlar almak ve böylelikle en doğru uzun vadeli tercihlere yönelmek olarak tanımlamaktadır. Bu çalışmada ise finansal okuryazarlık, bireyin parasını, varlıklarını, borçlarını kısacası bütçesini yönetmesi ile eşdeğer olarak kullanılan bir kavram olarak ele alındığı için 
paranın değerini etkileyebilecek enflasyon kavramı, faiz bilgisi, faiz hesaplama, paranın zaman değeri, tüketim, tasarruf gibi kavramlar gösterge olarak kullanılmıştır.

Finansal okuryazarlık anketlerine bakıldığında, örneğin 2010-2011 yılında gerçekleştirilen "OECD INFE Anketi”'inde ilk bölümde finansal bilginin, ikinci bölümde finansal davranışın ölçülmesi amaçlanmıştır. Finansal bilginin ölçümü için matematiksel bölme işlemi, basit ve bileşik faiz hesaplamaları, paranın zaman değeri, enflasyon, risk ve getiri kavramları ile risk çeşitlendirmesi konularını içeren sorular oluşturulmuştur. Finansal bilgi düzeyinin yüksek kabul edilebilmesi için sekiz sorudan en az altısının doğru cevaplandırılması gerekmektedir. Finansal davranışları ölçmenin amaçlandığı ikinci bölümde yer alan sorular ise, para yönetimi, bütçeleme, finansal karar alma süreçleri ve tasarruf etme gibi konuları içermekte olup, dokuz sorudan en az altısını doğru cevaplandıranların finansal okuryazarlık düzeyinin yüksek olduğuna karar verilmiştir.

$\mathrm{Bu}$ araştırmada anket soruları hem finansal bilgi hem de finansal davranışı ölçmeye yönelik olarak hazırlanmış, öğrencilerin sorulara verdikleri doğru cevapların sayısına bakmaktan ziyade, anketler finansal eğitim öncesi ve sonrasında olmak üzere iki kez uygulandığı için doğru cevaplardaki yüzdesel artışa bakılmış ve böylelikle öğrencilerin finansal bilgi ve davranışındaki değişikliği gözlemlemek şeklinde olmuştur. Anket sorularında, hedef kitle olarak seçilen öğrenci grubunun aşağıda belirtilen parametreler arasında ilişki kurması beklenmektedir:

-Üretim ve para ilişkisi

-Faiz ve para ilişkisi

-Tasarruf ve faiz ilişkisi

-Tasarruf yapmada bankaların rolü ve önemi

-Tüketim ve tasarruf ilişkisi

-Parayı doğru şekilde kullanabilme

-Tasarrufların ekonomik zenginleşme ile ilişkisi

-Borçlanma ve kredinin işleyişi ve ekonomideki önemi

-Enflasyonun gelire etkisi

-Bütçe yapmada tüketim ve tasarruf dengesini oluşturma

Araştırmanın ilk aşamasında, finansal eğitim öncesinde öğrencilerin finansal bilgi ve davranış seviyeleri anket uygulaması ile belirlenmiştir. İkinci aşamada 7. ve 8. sınıf ortaöğretim öğrencilerinin finansal okuryazarlık seviyelerini artıracak ve tasarruf bilinçlerini geliştirecek eğitimler verilmiştir. Bu çerçevede Ayvacık Meslek Yüksekokulu Finans-Bankacılık ve Sigortacılık bölümü 2. sinıf öğrencilerinden hem başarılı olduğu düşünülen hem de bu konuda gönüllü olan, seçilmiş öğrencilere 3 ay kadar bir zaman diliminde finansal okuryazarlık eğitimi verilmiş ve böylelikle ortaöğretimde eğitim verecek eğitimciler yetiştirilmiştir. Hem anketlerin uygulanması hem de finansal eğitimler, bu seçilmiş 13 Meslek Yüksekokulu öğrencisi tarafindan akademisyenlerin gözetiminde gerçekleştirilmiştir. Finansal okuryazarlık eğitimleri, ortaokulda eğitim gören öğrencilerin normal okul müfredatlarını aksatmayacak şekilde okulların yöneticileri ile yapılan planlama ve belirli bir koordinasyon çerçevesinde yürütülmüştür. Eğitimler için gerekli araç ve gereçler (bilgisayar, projeksiyon vb.) için okullardaki altyapı olanakları incelenmiş ve bu konuda herhangi bir sıkıntı ile karşılaşılmamıştır. Finansal eğitim öncesi Milli Eğitim okulları ile yapılan görüşmeler doğrultusunda ders programları hazırlanmıştır. Araştırmanın temel gereçleri; derslik, anket sorularını içeren fotokopiler, power-point şeklinde hazırlanan ders notlarının eğitim esnasında paylaşılması amacıyla bilgisayar, projeksiyon ve problem çözümleri için yazı tahtası ve tahta kalemleridir. Mevcut araç ve gereçler dahilinde her bir okulun ilgili dersliklerinde yüz yüze dersler anlatılmıştır. Eğitim sürecinin tamamlanması ile ardından örneklem grubunu oluşturan öğrencilere ikinci kez anket uygulanmıştır. Eğitim ve anket uygulaması tamamlandıktan sonra elde edilen veriler SPSS programına aktarılmış ve bu programda "eğitim öncesi" ve "eğitim sonrası" sonuçlarının karş1ıklı olarak değerlendirilebilmesine olanak tanıyan veriler elde edilmiştir. Durum tespiti ve sonuçların ölçme ve değerlendirilmesinde soru formlarına dayanan "nicel anket yöntemi" kullanılmıştır.

Araştırma kapsamında elde edilen veriler, öncelikle betimsel analiz tekniklerinden olan yüzde ve frekans analizi yapılmıştır. $\mathrm{Bu}$ analiz ile katılımcıların sorulara verdikleri cevapların dağılımı tespit edilmiştir. Ayrıca, ankete katılan öğrencilerin cinsiyetlerine göre finansal okuryazarlık sorularına verdikleri cevapların dağılımları görmek amacıyla çapraz tablo analizi (crosstab) ve yine öğrencilerin cinsiyetlerine 
göre anlamlı bir farklılık olup olmadığını tespit etmek amacıyla ise bağımsız örneklemler için t-testi uygulanmıştır.

\section{BULGULAR}

Hedef kitleye uygulanan ankette, ilk olarak öğrencilerin demografik özellikleri belirlenmiş, ardından tasarruf bilinci ve davranışları ortaya konulmuş, son olarak temel bankacılık ve temel ekonomi bilgileri ve günlük basit matematiksel işlemler yapma becerileri ile ölçülen finansal okuryazarlık düzeyleri, finansal eğitim öncesi ve sonrası olmak üzere değerlendirilmiştir.

\section{Öğrencilerin Sosyo-Demografik Özellikleri}

Araştırmaya katılan öğrencilerin sosyo-demografik özelliklerine ait frekans ve yüzdelik dağılımları Tablo 1'de yer almaktadır. Araştırmaya 320 öğrenci katılmıştır. Katılımcıların \%43,3'ü.kız, \%56,7'si erkektir. Öğrencilerin \%37,4'ü 7. sınıf, \%62,3'ü 8. sınıfta eğitim almaktadır. Buna göre erkek öğrenciler kız öğrencilere göre, 8. sınıf öğrenci sayısı, 7. sınıf öğrenci sayısına göre çoğunluktadır. Öğrencilerin ailelerinin gelir seviyelerinin düşük olduğu görülmektedir; 3.000 TL'nin altında gelir edenlerin $\% 40$ 'l1k bir kesimi kapsadığı görülmektedir. Anne ve babalarının eğitim düzeylerine bakıldığında ilköğretim mezunu olan annelerin oran $1 \% 63,9$, babaların oran $\% 56,1$, lise mezunu annelerin oran1 $\% 24$, babaların oran $1 \% 30,2$, üniversite mezunu olan anneler \%9,3, babalar ise 12,5 'dir. Yüksek öğrenim görmüş anne ve babalarının oranı ortalama \%10 seviyesinde iken, yarısından fazlasının ilköğretim mezunu olması öğrenci ailelerinin eğitim seviyelerinin genel olarak yüksek olmadığını göstermektedir.

Tablo 1. Katılımcıların Demografik Özelliklerine İlişkin Bulgular

\begin{tabular}{llll}
\hline Demografik Özellikler & & Frekans & Yüzde \\
\hline \multirow{2}{*}{ Cinsiyet } & Kiz & 139 & 43,3 \\
& Erkek & 182 & 56,7 \\
\hline \multirow{2}{*}{ Sınıf } & 7. Sınıf & 120 & 37,4 \\
& 8. Sınıf & 200 & 62,3 \\
\hline \multirow{2}{*}{ Ailenin Aylık Geliri } & 2000 TL'den az & 41 & 12,8 \\
& $2001-3000 \mathrm{TL}$ & 88 & 27,4 \\
& $3001-4000 \mathrm{TL}$ & 56 & 17,4 \\
& $4001-5000 \mathrm{TL}$ & 37 & 11,5 \\
& 5001 TL ve üzeri & 56 & 17,4 \\
\hline \multirow{2}{*}{ Babanın Eğitim Düzeyi } & İlköğretim & 180 & 56,1 \\
& Lise & 97 & 30,2 \\
\multirow{2}{*}{ Annenin Eğitim Düzeyi } & Üniversite & 40 & 12,5 \\
& İlköğretim & 205 & 63,9 \\
& Lise & 77 & 24,0 \\
\hline
\end{tabular}

Finansal Okuryazarlık Bilgi Düzeyine İlişkin Bulgular

\section{-Tasarruf Bilinci ve Davranışı}

Finansal eğitime katılan öğrencilerin tasarruf bilinci ve tasarruf davranışını ölçmeye yönelik oluşturulan sorular ve bu sorulara verilen cevapların dağılımı Tablo $2 \mathrm{a}$ ve $2 \mathrm{~b}$ 'de görülmektedir.

Tablo 2a. Katılımcıların Tasarruf Bilinci ve Davranışı

\begin{tabular}{llll} 
Göstergeler & Seçenekler & Frekans & Yüzde \\
\hline \multirow{2}{*}{ Ailelerin aylık harcama planı yapması } & Evet & 167 & 52 \\
& Hayır & 139 & 43,3 \\
& Cevap vermeyen & 15 & 4,7 \\
\hline \multirow{3}{*}{ Ailelerden harçlık alınması } & Evet, hergün & 205 & 63,9 \\
& Evet, bazı günler & 111 & 34,6 \\
& Hayır & 3 & 0,9 \\
& Cevap vermeyen & 2 & 0,6 \\
\hline
\end{tabular}




\begin{tabular}{|c|c|c|c|}
\hline \multirow{3}{*}{ Harçlığın tamamının harcanması } & Evet & 106 & 33 \\
\hline & Hayır & 207 & 64,5 \\
\hline & Cevap vermeyen & 8 & 2,5 \\
\hline \multirow{3}{*}{ Kumbara kullanımı } & Evet & 201 & 62,6 \\
\hline & Hayır & 119 & 37,1 \\
\hline & Cevap vermeyen & 1 & 0,3 \\
\hline \multirow{3}{*}{ Tasarruf yapmada kumbaranın rolü } & Evet & 264 & 82,2 \\
\hline & Hayır & 54 & 16,8 \\
\hline & Cevap vermeyen & 3 & 0,9 \\
\hline \multirow{3}{*}{ Harcama planı yapma } & Evet & 227 & 70,7 \\
\hline & Hayır & 92 & 28,7 \\
\hline & Cevap vermeyen & 2 & 0,6 \\
\hline \multirow{3}{*}{ Düzenli olarak para biriktirme } & Evet & 200 & 62,3 \\
\hline & Hayır & 120 & 37,4 \\
\hline & Cevap vermeyen & 1 & 0,3 \\
\hline \multirow{5}{*}{ Para biriktirmeme nedeni } & $\begin{array}{l}\text { Gelirin düşük } \\
\text { olması }\end{array}$ & 7 & 2,2 \\
\hline & $\begin{array}{l}\text { Tasarruf yapmanın } \\
\text { anlamsız olması }\end{array}$ & 5 & 1,6 \\
\hline & $\begin{array}{l}\text { Parayı harcamanın } \\
\text { daha keyifli olması }\end{array}$ & 55 & 17,1 \\
\hline & Bilmiyorum & 78 & 24,3 \\
\hline & Cevap vermeyen & 176 & 54,8 \\
\hline \multirow{3}{*}{ Malların fiyatlarını kıyaslama } & Evet & 261 & 81,3 \\
\hline & Hayır & 53 & 16,5 \\
\hline & $\begin{array}{l}\text { Cevap } \\
\text { vermeyen }\end{array}$ & 7 & 2,2 \\
\hline \multirow{3}{*}{$\begin{array}{l}\text { Tüketim-tasarruf ilişkisini kavrama } \\
\text { (Daha fazla tüketimin daha az tasarrufa yol açması) }\end{array}$} & Evet & 206 & 64,2 \\
\hline & Hayır & 104 & 32,4 \\
\hline & $\begin{array}{l}\text { Cevap } \\
\text { vermeyen }\end{array}$ & 11 & 3,4 \\
\hline
\end{tabular}

Tasarruf bilincinin ailede kazanılan bir alışkanlık olduğu düşünülerek, öğrencilere ailelerinde aylık harcama planının yapılıp yapılmadığı sorulmuş (Tablo $2 \mathrm{a}$ ), \%.52'i evet, \%43,3'ü hayır cevabını vermiştir. Öğrencilerin \%63,9'u ailelerinden hergün harçlık alırken, bazı günler harçlık alanların oranı \%34,4'dür. Harçlığının tamamını harcayanların oranı \%33 iken, tamamını harcamayanların oranı \%64,5'dir. Diğer taraftan bir kumbaraya sahip olmanın öğrencileri tasarruf yapmaya teşvik etmedeki rolünü öğrenmek amacıyla kumbara kullanıp kullanmadıkları sorulmuş bu soruya \%.62,6'sı evet, \%37,1'i hayır cevabını vermiştir. Bir kumbaraya sahip olmanın para biriktirme ve tasarruf yapma davranışını etkileyeceğini düşünenlerin oranı \%82,2, etkili olmadığını düşünenlerin oranı 16,8'dir. Öğrencilerin büyük çoğunluğu tasarruf yapmada kumbaranın rolüne inanmaktadırlar.

Tablo 2a'da görüldüğü gibi öğrencilerin \% 70,7'si paralarını nasıl, nerede ve ne zaman harcayacakları ile ilgili plan yapmakta ve \%62,3'ü parasını düzenli olarak biriktirmektedir. Parasını biriktirmeyenlere bunun nedenleri sorulduğunda, yanıt verenlerin \%2,2'si gelirinin düşük olmasını gösterirken, \%1,6's1 tasarruf yapmayı anlamsız bulmakta, \%17,1'i parayı harcamanın daha keyifli olduğunu düşünmekte, $\% 24,3$ 'ü ise nedenini bilmemektedir. Öğrencilerin tasarruf bilincini ölçmek amacıyla alışverişlerde satın alacakları malların fiyatlarına ilişkin bir kıyaslama yapıp yapmadıkları sorulmuş ve \%81,3'nün fiyat kıyaslaması yaptığı görülmüştür. Öğrencilerin tüketim ve tasarruf arasındaki ilişkiyi ne ölçüde kavradıklarını görebilmek amacıyla "ne kadar çok tüketirsek o kadar az tasarruf yapmış oluruz, paramız daha az birikir" ifadesinin doğru olup olmadığı sorulmuş ve \%64'ü doğru cevap vermiştir. Bu cevaplara 
bakıldığında öğrencilerin ailelerinin yarısından fazlasının aylık harcama planı yaptığı ve öğrencilerin de yarısından fazlasının tüketim-tasarruf dengesi kurmaya çalıştığını tespit edebiliriz. Bu sonuçlar SPK'nın 2012 yılında yapmış olduğu "Finansal Yeterlilik Anketi”"nde kırsal bölgede tasarruf yapma eğiliminin yüksek olduğu (kentsel bölgelere göre) sonuçlarıyla da uyumludur.

Finansal eğitim boyunca, öğrencilere bir işte çalışmadıkları halde evde uygulayabilecekleri birçok tasarruf tedbirlerinden bahsedilmiştir. Finansal eğitim sonrası öğrencilerin aile içi tasarruf davranışlarında bir değişiklik olup olmadığına bakıldığında, aile bütçesine katkı sağlayan öğrencilerin oranı finansal eğitim öncesi \%66 iken, bu oran finansal eğitim sonras 1 \% 72'ye yükselmiştir. Hedef kitle olarak seçilen grubun genel olarak aile gelirinin düşük olması finansal eğitim öncesinde de öğrencilerin tasarruf eğiliminin düşük olmadığını ancak finansal eğitim sonrası öğrencilerin tasarruf farkındalıklarının daha fazla arttığını söyleyebiliriz. Öğrencilerin parayı doğru bir şekilde kullanma davranışlarını değerlendirmek amacıyla sorulan bir soruda (Tablo 2b), ailelerinin gelirlerinin ay başından önce tükenmesi durumunda ne yapmasının daha doğru olacağı sorulmuş, cevap verenlerin $\% 2,8$ 'i ev, araba gibi varlıkların satılması gerektiğini düşünürken, \%15,9'u akraba, çevre ya da bankadan borç alınmasını, \%3,7'si ek iş yaparak para kazanmasını ve \%72,3'ü de önceki aylarda gelirinin bir kısmını harcamaması ve biriktirmesi gerektiğini düşünmektedir. Eğitim sonrasında bu oranlar sırasıyla; $\% 2,8, \% 8,1, \% 5,6$ ve \%81,6 olarak değişmiştir. Bu sorudaki doğru cevap "önceki aylarda gelirinin bir kısmını harcamaması ve biriktirmesi” seçeneği olduğu için eğitim sonrasında öğrencilerin tasarruf bilinçlerinin daha da yükseldiğini söylemek mümkündür.

Tablo 2b. Katılımcıların Tasarruf Bilinci ve Davranışı

\begin{tabular}{|c|c|c|c|c|c|}
\hline \multirow[b]{2}{*}{ Göstergeler } & \multirow[b]{2}{*}{ Seçenekler } & \multicolumn{2}{|c|}{ Eğitim Öncesi } & \multicolumn{2}{|c|}{ Eğitim sonrası } \\
\hline & & Frekans & Yüzde & Frekans & Yüzde \\
\hline \multirow{3}{*}{ Aile bütçesine katkı } & Evet & 212 & 66 & 231 & 72 \\
\hline & Hayır & 96 & 29,9 & 84 & 26,2 \\
\hline & Cevap vermeyen & 13 & 4 & 6 & 1,9 \\
\hline \multirow{4}{*}{$\begin{array}{l}\text { Tasarrufun önemini } \\
\text { kavrama (aybaşından önce } \\
\text { gelirin tükenmesi) }\end{array}$} & Ev, araba gibi varlıklarını satması & 9 & 2,8 & 9 & 2,8 \\
\hline & Ek iş yaparak para kazanması & 51 & 15,9 & 26 & 8,1 \\
\hline & $\begin{array}{l}\text { Akraba, çevre ya da bankadan borç } \\
\text { alması }\end{array}$ & 12 & 3,7 & 18 & 5,6 \\
\hline & $\begin{array}{l}\text { Önceki aylarda gelirinin bir kısmını } \\
\text { harcamaması ve biriktirmesi }\end{array}$ & 232 & 72,3 & 262 & 81,6 \\
\hline
\end{tabular}

\section{-Temel Finansal Okuryazarlık Bilgisi}

Öğrencilere temel finansal okuryazarlık bilgilerini ölçmek amacıyla temel bankacılık ve temel ekonomi bilgilerini içeren sorular yöneltilmiştir. Bankanın önemini anlama ve işlevini kavrama, bankacılık temel bilgileri ile ilgili olarak öğrencilere yöneltilen sorulara verilen cevaplar değerlendirildiğinde (Tablo 3a), eğitim öncesi öğrencilerin $\% 75,7$ 'si, eğitim sonrası $\% 85$ 'i biriktirilen paranın evde değil, bir banka hesabında bulundurulmasının daha güvenli olduğunu düşünmektedir. Birçok bankanın çocukların para biriktirmelerini sağlamak ve onları tasarrufa yönlendirmek için "turuncu çocuk hesabı", "birikimli mevduat hesabı", "ilk imza hesabı" gibi uygulamalarından öğrencilerin \%26,8'si eğitim öncesi haberdar olduğunu belirtirken bu oran eğitim sonrasında \%76'ya yükselmiştir. Bankacılık uygulamaları ile ilgili olarak gençlerin bilgilendirilmesinin yararlı olduğu görülmektedir.

Tablo 3a. Temel Finansal Okuryazarlık Bilgisi (Temel Banka Bilgileri)

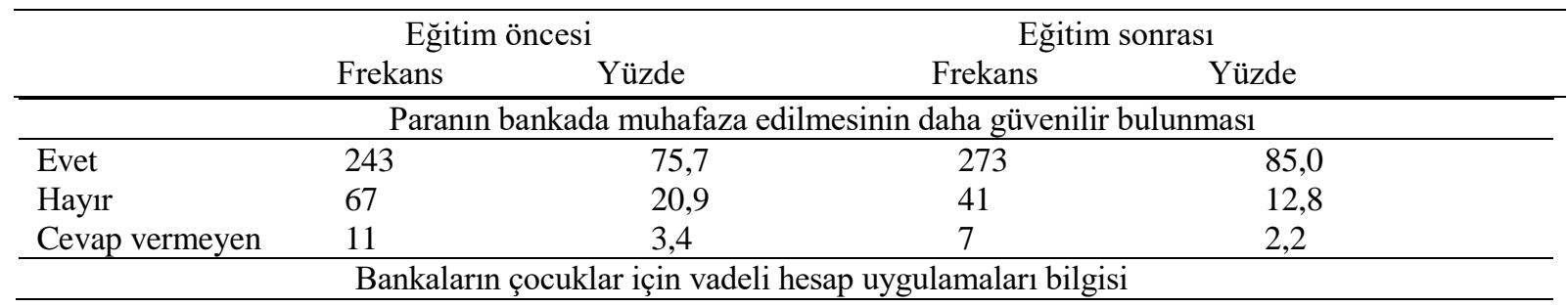




\begin{tabular}{|c|c|c|c|c|}
\hline Evet & 86 & 26,8 & 244 & 76,0 \\
\hline Hayır & 224 & 69,8 & 73 & 22,7 \\
\hline Cevap vermeyen & 11 & 3,4 & 4 & 1,2 \\
\hline \multicolumn{5}{|c|}{ Banka hesapları bilgisi (Çocukların yasal olarak hesap açabilmesi) } \\
\hline Evet & 216 & 67,3 & 246 & 76,6 \\
\hline Hayır & 94 & 29,3 & 69 & 21,5 \\
\hline Cevap vermeyen & 11 & 3,4 & 6 & 1,9 \\
\hline \multicolumn{5}{|c|}{ Vadeli hesap bilgisi } \\
\hline Evet & 178 & 55,5 & 253 & 78,8 \\
\hline Hayır & 132 & 41,1 & 59 & 18,4 \\
\hline Cevap vermeyen & 11 & 3,4 & 9 & 2,8 \\
\hline \multicolumn{5}{|c|}{ Faiz bilgisi } \\
\hline Evet & 201 & 62,6 & 254 & 79,1 \\
\hline Hayır & 98 & 30,5 & 55 & 17,1 \\
\hline Cevap vermeyen & 22 & 6,9 & 12 & 3,7 \\
\hline \multicolumn{5}{|c|}{ Para-üretim bilgisi (Bankaya yatırılan paranın kullanımı) } \\
\hline Harcanır & 43 & 13,4 & 29 & 9,0 \\
\hline $\begin{array}{l}\text { Kasada tutulur, } \\
\text { kullanılmaz }\end{array}$ & 166 & 51,7 & 55 & 17,1 \\
\hline $\begin{array}{l}\text { İhtiyacımızı } \\
\text { karşılayan malları } \\
\text { üreten işletmelere } \\
\text { borç } \quad \text { verir, } \\
\text { işletmeler bu paray } \\
\text { kullanarak üretim } \\
\text { yaparlar }\end{array}$ & 27 & 8,4 & 212 & 66,0 \\
\hline Bilmiyorum & 73 & 22,7 & 22 & 6,9 \\
\hline Cevap vermeyen & 12 & 3,7 & 3 & 0,9 \\
\hline
\end{tabular}

Banka temel bilgisinin ölçülmesinde kullanılan bir diğer soruda (Tablo 3a), öğrencilerin \%67,3’ü 18 yaşından küçük olanların, anne ve babalarının veya yasal vasisi olmadan banka hesabı açtırmayacakları konusunda bilgi sahibi iken, bu bilgi düzeyinin eğitim sonrasında yükseldiği görülmektedir $(\% 76,6)$. Eğitime katılan öğrencilerin temel bankacılık bilgilerini ölçmek için vadeli hesap ve faiz kavramına ilişkin sorular yöneltilmiştir. Biriktirilen paranın, bir bankada "vadeli mevduat" adı altında bir hesap açıp yatırıldığında belirli bir süre sonra (aylık, üç aylık, yıllık) paranın daha fazla olacağını bilgisine öğrencilerin \%55,5'i sahip iken bu oran eğitim sonrasında \% $\% 8,8$ 'e yükselmiştir.

Eğitim kapsamında hedeflenen amaçlardan biri de gençlerin, faizin para ekonomisinde neden gerekli bir mekanizma olduğunu anlamalarını sağlamaktı. Bu çerçevede öğrencilere bazı sorular yöneltilmiştir. Paramızı bankaya yatırdığımızda, bankanın bu parayı kullanacağı için bize karşılığında fazladan bir para ödeyeceği ve buna da faiz denildiği bilgisine, öğrencilerin \%62,6's1 sahip iken eğitim sonrasında bu oranın $\% 79,1$ 'e yükseldiği görülmektedir. Bu soru aynı zamanda öğrencilerin para-faiz ilişkisini ne oranda kavradığını ölçmektedir. Araştırma kapsamında gençlerin kavraması istenilen bir başka konu ise tasarruf-para-banka-üretim ilişkisi olduğu için eğitim süresince bu konuda temel bilgiler aktarılmış ve bunu ölçmeye yönelik sorular yöneltilmiştir. Bir bankaya yatırılan paranın banka tarafından harcanacağını düşünenlerin oranı $\% 13,4$, kasada tutulup harcanmayacağını düşünenlerin oran $1 \% 51,7$, ihtiyacımızı karşılayan malları üreten işletmelere borç verip, işletmelerin de bu parayı kullanarak üretim yapacaklarını düşünenlerin oranı $\% 8,4 \mathrm{iken}$, bu oranlar eğitim sonrasında sırasıyla, $\% 9, \% 17,1$ ve $\% 66$ olarak değişmiştir. Eğitim öncesi ve sonrası cevaplar karşılaştırıldığında öğrencilerin finansal okuryazarlık bilgi düzeylerinin arttığı görülmektedir.

Araştırma kapsamında yürütülen finansal eğitimde hedeflenen amaçlardan biri de, öğrencilerin faiz hesaplamalarını yapabilmelerini sağlamaktı. Buna ilişkin ankette (Tablo 3b) hem basit faiz hem de bileşik faizle ilgili sorulara yer verilmiştir. Özellikle basit faiz hesaplamasında öğrencilerin ilgili soruya verdikleri doğru cevap oranı eğitim öncesi \%37,1 iken, eğitim sonrasında bu oran \%81,9'a yükselmiştir. 
Ancak bileşik faiz hesaplamasında öğrencilerin zorlandıkları ama yine de eğitim sonrasında bu konuya ilişkin soruda doğru cevap oranının yükseldiği görülmektedir. Sonuç itibariyle, bankaların ekonomideki önemini ve aracılık işlevini kavrama, bankaların üretimdeki rolü ve etkisi, faizin para ekonomisindeki rolü, vadeli hesapların para birikimine etkisi ve faiz hesaplama gibi konularda eğitime katılan öğrencilerin bilgi seviyelerinin önemli oranda arttığı gözlenmektedir.

Tablo 3b. Temel Finansal Okuryazarlı Bilgisi (Faiz Hesaplama)

\begin{tabular}{llclc}
\hline \multicolumn{5}{c}{ Basit faiz hesaplama } \\
\hline & \multicolumn{2}{c}{ Eğitim öncesi } & \multicolumn{2}{c}{ Eğitim sonrası } \\
& Frekans & Yüzde & Frekans & Yüzde \\
\hline 105 TL'den az & 15 & 4,7 & 11 & 3,4 \\
105 TL'den fazla & 75 & 23,4 & 26 & 8,1 \\
Tam 105 TL & 119 & 37,1 & 263 & 81,9 \\
Bilmiyorum & 93 & 29 & 17 & 5,3 \\
Cevap vermeyen & 19 & 5,9 & 4 & 1,2 \\
\hline \multicolumn{5}{c}{ Bileşik faiz hesaplama } \\
\hline & Eğitim öncesi & Eğitim sonras1 \\
& Frekans & Yüzde & Frekans & Yüzde \\
\hline 200 TL'den fazla & 75 & 23,4 & 62 & 19,3 \\
200 TL'den az & 82 & 25,5 & 122 & 38 \\
Tam 200 TL & 27 & 8,4 & 89 & 27,7 \\
\hline
\end{tabular}

Tablo 4'de yer alan sorular ise, temel ekonomi bilgisini ölçmeyi amaçlamaktadır. İlk iki soru, harcama alışkanlıkları, tüketim ve borçlanma arasındaki ilişkinin ne düzeyde algılandığını gösteren ve günümüzde ödemelerde sıklıkla kullanılan kredi kartı hakkındadır. Kredi kartı kullanımının gelirimiz limitinde yapılması gerektiği ve gelirimizden daha fazlasını harcamanın borçlanmak anlamına geleceğini düşünen gençlerin oranı eğitim öncesinde $\% 67,6$ iken, eğitim sonrasında bu oran $\% 72,9$ seviyesine yükselmiştir. Harcamalarımızı kontrol etmek için kredi kartı kullanımına bir sınır getirmesi gerektiğini, örneğin kredi kartının aylık taksitlerinin, gelirimizin 1/4’ünü geçmemesi gerektiği düşüncesine katılanların oranı 71,3'den 77,9'a yükselmiştir.

Tablo 4. Temel Ekonomi Bilgisi

\begin{tabular}{|c|c|c|c|c|}
\hline & \multicolumn{2}{|c|}{ Eğitim Öncesi } & \multicolumn{2}{|c|}{ Eğitim sonras1 } \\
\hline & Frekans & Yüzde & Frekans & Yüzde \\
\hline & \multicolumn{4}{|c|}{ Kredi kartı-borçlanma ilişkisini anlama } \\
\hline Evet & 217 & 67,6 & 234 & 72,9 \\
\hline Hayır & 88 & 27,4 & 79 & 24,6 \\
\hline \multirow[t]{2}{*}{ Cevap vermeyen } & 16 & 5 & 8 & 2,5 \\
\hline & \multicolumn{4}{|c|}{ Kredi kartı limiti-gelir ilişkisini kavrama } \\
\hline Evet & 229 & 71,3 & 250 & 77,9 \\
\hline Hayır & 72 & 22,4 & 64 & 19,9 \\
\hline \multirow[t]{2}{*}{ Cevap vermeyen } & 20 & 6,2 & 7 & 2,2 \\
\hline & \multicolumn{4}{|c|}{$\begin{array}{l}\text { Enflasyon ve satın alma gücü arasındaki ilişkiyi } \\
\text { kavrama }\end{array}$} \\
\hline Evet & 204 & 63,6 & 234 & 72,9 \\
\hline Hayır & 93 & 29 & 82 & 25,5 \\
\hline \multirow[t]{2}{*}{ Cevap vermeyen } & 24 & 7,5 & 5 & 1,6 \\
\hline & \multicolumn{4}{|c|}{ Enflasyon kavramı } \\
\hline Evet & 105 & 32,7 & 257 & 80,1 \\
\hline Hayır & 200 & 62,3 & 56 & 17,4 \\
\hline
\end{tabular}




\begin{tabular}{|c|c|c|c|c|}
\hline Cevap vermeyen & 16 & 5 & 8 & 2,5 \\
\hline & \multicolumn{4}{|c|}{ Paranın zaman değeri-enflasyon ilişkisi } \\
\hline Bugünden fazla & 57 & 17,8 & 68 & 21,2 \\
\hline Bugünden az & 63 & 19,6 & 88 & 27,4 \\
\hline Tamamen aynı & 81 & 25,2 & 101 & 31,5 \\
\hline Bilmiyorum & 104 & 32,4 & 48 & 15 \\
\hline \multirow[t]{2}{*}{ Cevap vermeyen } & 16 & 5 & 16 & 5 \\
\hline & \multicolumn{4}{|c|}{ Paranın zaman değeri } \\
\hline Arkadaşınız ailesi & 105 & 32,7 & 94 & 29,3 \\
\hline Sizin aileniz & 85 & 26,5 & 82 & 25,5 \\
\hline $\begin{array}{l}\text { Her ikisi de eşit } \\
\text { oranda zengin olur }\end{array}$ & 52 & 16,2 & 100 & 31,2 \\
\hline Bilmiyorum & 64 & 19,9 & 38 & 11,8 \\
\hline Cevap vermeyen & 15 & 4,7 & 7 & 2,2 \\
\hline \multirow[t]{2}{*}{ Cevap vermeyen } & 23 & 7,2 & 9 & 2,8 \\
\hline & \multicolumn{4}{|c|}{ Paranın işlevini kavrama } \\
\hline Evet & 235 & 73,2 & 251 & 78,2 \\
\hline \multirow[t]{2}{*}{ Hayır } & 63 & 19,6 & 61 & 19 \\
\hline & \multicolumn{4}{|c|}{ İhtiyaç ve istek ayrımını yapabilme } \\
\hline Evet & 227 & 70,7 & 262 & 81,6 \\
\hline Hayır & 71 & 22,1 & 53 & 16,5 \\
\hline Cevap vermeyen & 23 & 7,2 & 6 & 1,9 \\
\hline
\end{tabular}

Yine Tablo 4'de, ihtiyaç ve istek arasındaki farkı anlama, paranın ekonomideki rolü, paranın zaman değeri, enflasyon kavramı bilgisi, enflasyon ve satın alma gücü arasındaki ilişkiyi kavrama ve anlamaya yönelik soruların değerlendirmeleri yer almaktadır. Özellikle enflasyon bilgisinin eğitim öncesinde düşük olduğu eğitim sonrasında bu seviyenin büyük oranda yükseldiği görülmektedir $(\% 32,7$ den $\% 80,1)$ Benzer şekilde enflasyon ve paranın satın alma gücü arasındaki ilişkiyi doğru kavrayanların oranı eğitim sonrasında artmıştır. Bir ülke ekonomisinin zenginleşmesinin o ülkenin yapacağı üretimle doğru orantılı olacağını düşünen gençlerin oranı eğitim öncesinde de yüksek iken, eğitim sonrasında biraz daha artmıştır. Diğer taraftan ihtiyaçlar ile istekler arasındaki farkın kavranmasında gençlerin algı düzeyinin yüksek olduğu, eğitim sonrasında bu konudaki farkındalığın daha da arttı̆̆ görülmektedir.

Tablo 5. Günlük Basit Hesaplamalar

\begin{tabular}{|c|c|c|c|c|}
\hline \multirow[b]{2}{*}{ Seçenekler } & \multicolumn{2}{|c|}{ Eğitim Öncesi } & \multicolumn{2}{|r|}{ Eğitim sonrası } \\
\hline & Frekans & Yüzde & Frekans & Yüzde \\
\hline \multicolumn{5}{|c|}{$\begin{array}{l}\text { Aylık geliriniz } 2.500 \text { TL ise, gelirinizin } 500 \text { TL'sini tasarruf } \\
\text { ederseniz, gelirinizin yüzde kaçını tasarruf etmiş olursunuz? }\end{array}$} \\
\hline $40 \%$ & 40 & 12,5 & 17 & 5,3 \\
\hline $30 \%$ & 48 & 15 & 36 & 11,2 \\
\hline $20 \%$ & 148 & 46,1 & 233 & 72,6 \\
\hline $10 \%$ & 55 & 17,1 & 27 & 8,4 \\
\hline Cevap vermeyen & 30 & 9,3 & 8 & 2,5 \\
\hline & \multicolumn{4}{|c|}{$\begin{array}{l}\text { Ahmet aylık } 3.000 \text { TL kazanmaktadır. Aylık, } 1.000 \text { TL kira ödemekte, } \\
1.200 \text { TL mutfak masrafı, } 300 \mathrm{TL} \text { ulaşım masrafi, } 350 \mathrm{TL} \text { diğer } \\
\text { harcamalar için ayırmaktadır. Ahmet'in aylık kazandığ para ve } \\
\text { harcamalara göre } 600 \mathrm{TL} \text { para biriktirmesi için ne kadar süre geçmesi } \\
\text { gerekmektedir? }\end{array}$} \\
\hline Bir ay & 42 & 13,1 & 13 & 4 \\
\hline
\end{tabular}




\begin{tabular}{|c|c|c|c|c|}
\hline İki ay & 43 & 13,4 & 19 & 5,9 \\
\hline Dört ay & 60 & 18,7 & 203 & 63,2 \\
\hline Altı ay & 134 & 41,7 & 82 & 25,5 \\
\hline \multirow[t]{2}{*}{ Cevap vermeyen } & 42 & 13,1 & 4 & 1,2 \\
\hline & \multicolumn{4}{|c|}{$\begin{array}{l}\text { "Ayşe internetten satın alacağı kitap iç̧in, A kitabevinde fiyatın } 20 \text { TL, } \\
\text { B kitabevinde ise } 3 \text { dolar (\$) olduğunu görmüştür. } 1 \text { doların } 6 \text { TL } \\
\text { olduğunu varsayalım. Buna göre Ayşe'nin, A kitabevinden kitabı alması } \\
\text { daha hesaplı değildir." ifadesinin doğru olduğunu düşünüyor musunuz? }\end{array}$} \\
\hline Evet & 190 & 59,2 & 229 & 71,3 \\
\hline Hayır & 100 & 31,2 & 85 & 26,5 \\
\hline \multirow[t]{2}{*}{ Cevap vermeyen } & 31 & 9,7 & 7 & 2,2 \\
\hline & \multicolumn{4}{|c|}{$\begin{array}{l}\text { Ali ve Mustafa fiyatı } 2.000 \text { TL olan cep telefonunu satın almak için para } \\
\text { biriktirmeye karar vermişlerdir. Başlangıcta Ali'nin } 1000 \text { TL.' si, } \\
\text { Mustafa'nın } 800 \text { TL'si vardır. Bir yıl boyunca Ali her ay } 80 \text { TL, Mustafa } \\
\text { ise } 100 \text { TL biriktirdiğinde, aşağıdaki seçeneklerden hangisi doğru olur? }\end{array}$} \\
\hline $\begin{array}{l}\text { Bir yıl sonra her ikisi de telefonu } \\
\text { satın alabilir }\end{array}$ & 91 & 28,3 & 45 & 14 \\
\hline $\begin{array}{l}\text { Bir yıl sonra telefonu sadece Ali } \\
\text { satın alabilir }\end{array}$ & 52 & 16,2 & 41 & 12,8 \\
\hline $\begin{array}{l}\text { Bir yıl sonra telefonu sadece } \\
\text { Mustafa satın alabilir }\end{array}$ & 108 & 33,6 & 206 & 64,2 \\
\hline $\begin{array}{l}\text { Bir yıl sonra telefonu her ikisi de } \\
\text { alamaz }\end{array}$ & 39 & 12,1 & 21 & 6,5 \\
\hline Cevap vermeyen & 31 & 9,7 & 8 & 2,5 \\
\hline
\end{tabular}

Son olarak ankette, gençlerin günlük basit hesaplamaları ne ölçüde yapabildiğini ölçmeye yönelik sorulara yer verilmiştir. Tablo 5'de görüldügüü gibi eğitim öncesi verilen cevaplarla eğitim sonrasi verilen cevaplar karşılaştırıldığında finansal eğitim sonrası doğru cevaplara verilen oranın yüzdesel olarak yükseldiği görülmektedir.

$\mathrm{Bu}$ araştırmada, tasarruf bilinci ve tasarruf davranışı, temel bankacılık bilgisi, faiz hesaplamaları, temel ekonomi bilgisi ve günlük basit harcamaları yapabilme becerisinin cinsiyet, yaş, gelir düzeyi ve ailenin eğitim durumu ile olan ilişkilerine bakılmış cinsiyet haricinde diğer değişkenler anlamlı çıkmamıştır. Tablo 6a, 6b,6c, 6d, 6e'de cinsiyet ile finansal okuryazarlık soruları arasındaki ilişkiyi belirlemek amacıyla öncelikle çapraz tablo analizi (crosstab) yapılmıştır. Daha sonra ise cinsiyet ile finansal okuryazarlık soruları arasında istatistiki olarak anlamlı bir ilişki olup olmadığı bağımsız örneklemler için t-testi ile tespit edilmiştir. Buna göre, aşağıda yer alan tablolar incelendiğinde cinsiyet ile tüm sorular arasında 0,05 anlamlılık düzeyinde önemli bir farklılık vardır. Burada dikkat edilmesi gereken husus ise, eğitim öncesine göre eğitim sonrasında bu önemli farkın daha da belirginleştiğidir. Bu sonuç, eğitimin finansal okuryazarlık düzeyini arttırdığı şeklinde yorumlanabilir. Bir diğer husus ise, finansal okuryazarlık sorularına kız öğrencilerin erkek öğrencilere göre daha fazla doğru yanıt verdiği görülmektedir. Bu durum kız öğrencilerin finansal okuryazarlık konusunda erkek öğrencilere göre daha başarılı olduğu şeklinde ifade edilebilir. 
Tablo 6a. Cinsiyet ve Finansal Okuryazarlık Iliş̧kisi

\begin{tabular}{|c|c|c|c|c|c|c|c|c|}
\hline \multirow{4}{*}{ Seçenekler } & \multicolumn{8}{|c|}{ TASARRUF BİLINCİ VE DAVRANIȘI } \\
\hline & \multicolumn{4}{|c|}{ Eğitim Öncesi } & \multicolumn{4}{|c|}{ Eğitim sonrası } \\
\hline & \multicolumn{2}{|c|}{$\mathrm{K} 1 \mathrm{z}$} & \multicolumn{2}{|c|}{ Erkek } & \multicolumn{2}{|c|}{$\mathrm{K}_{12}$} & \multicolumn{2}{|c|}{ Erkek } \\
\hline & Yüzde & Frekans & Yüzde & Frekans & Yüzde & Frekans & Yüzde & Frekans \\
\hline Doğru & 69,38 & 868 & 63,98 & 1048 & 77,62 & 971 & 62,88 & 1030 \\
\hline Yanlış & 30,62 & 383 & 36,02 & 590 & 22,38 & 280 & 37,12 & 608 \\
\hline Toplam & 100 & 1251 & 100 & 1638 & 100 & 1251 & 100 & 1638 \\
\hline P değeri & \multicolumn{4}{|c|}{$0,05 *$} & \multicolumn{4}{|c|}{$0,02 *$} \\
\hline
\end{tabular}

$$
* * *: \mathrm{p}<0.001 \quad * *: \mathrm{p}<0.01 \quad *: \mathrm{p}<0.05
$$

Tablo 6b. Cinsiyet ve Finansal Okuryazarlık İlişkisi

\begin{tabular}{|c|c|c|c|c|c|c|c|c|}
\hline \multirow{4}{*}{ Seçenekler } & \multicolumn{8}{|c|}{ TEMEL BANKACILIK BİLGİSİ } \\
\hline & \multicolumn{4}{|c|}{ Eğitim Öncesi } & \multicolumn{4}{|c|}{$\begin{array}{ll}\text { Eğitim sonras1 } \\
\end{array}$} \\
\hline & \multicolumn{2}{|c|}{$\mathrm{K} 1 \mathrm{Z}$} & \multicolumn{2}{|c|}{ Erkek } & \multicolumn{2}{|c|}{$\mathrm{K} 1 \mathrm{Z}$} & \multicolumn{2}{|c|}{ Erkek } \\
\hline & Yüzde & Frekans & Yüzde & Frekans & Yüzde & Frekans & Yüzde & Frekans \\
\hline Doğru & 51,08 & 497 & 53,30 & 679 & 87,25 & 849 & 71,90 & 916 \\
\hline Yanlış & 48,92 & 476 & 46,70 & 294 & 12,75 & 124 & 28,10 & 358 \\
\hline Toplam & 100 & 973 & 100 & 1274 & 100 & 973 & 100 & 1274 \\
\hline P değeri & \multicolumn{4}{|c|}{$0,05^{*}$} & \multicolumn{4}{|c|}{$0,03^{*}$} \\
\hline
\end{tabular}

$* * *: \mathrm{p}<0.001 \quad * *: \mathrm{p}<0.01 \quad *: \mathrm{p}<0.05$

Tablo 6c. Cinsiyet ve Finansal Okuryazarlık İlişkisi

\begin{tabular}{|c|c|c|c|c|c|c|c|c|}
\hline \multirow{4}{*}{ Seçenekler } & \multicolumn{8}{|c|}{ FAİZ HESAPLAMALARI } \\
\hline & \multicolumn{4}{|c|}{ Eğitim Öncesi } & \multicolumn{4}{|c|}{ Eğitim sonrası } \\
\hline & \multicolumn{2}{|c|}{$\mathrm{K}_{1 \mathrm{Z}}$} & \multicolumn{2}{|c|}{ Erkek } & \multicolumn{2}{|c|}{$\mathrm{K} 1 \mathrm{Z}$} & \multicolumn{2}{|c|}{ Erkek } \\
\hline & Yüzde & Frekans & Yüzde & Frekans & Yüzde & Frekans & Yüzde & Frekans \\
\hline Doğru & 25,54 & 71 & 35,71 & 130 & 61,87 & 172 & 58,51 & 213 \\
\hline Yanlış & 74,46 & 207 & 64,29 & 234 & 38,13 & 106 & 41,49 & 151 \\
\hline Toplam & 100 & 278 & 100 & 364 & 100 & 278 & 100 & 364 \\
\hline $\mathrm{P}$ değeri & \multicolumn{4}{|c|}{$0,001 * * *$} & \multicolumn{4}{|c|}{$0,000 * * *$} \\
\hline
\end{tabular}

$* * *: p<0.001 \quad * *: p<0.01 *: p<0.05$

Tablo 6d. Cinsiyet ve Finansal Okuryazarlık İlişkisi

\begin{tabular}{|c|c|c|c|c|c|c|c|c|}
\hline \multirow{4}{*}{ Seçenekler } & \multicolumn{8}{|c|}{ TEMEL EKONOMİ BİLGİSİ } \\
\hline & \multicolumn{4}{|c|}{ Eğitim Öncesi } & \multicolumn{4}{|c|}{$\begin{array}{l}\text { Eğitim sonras1 } \\
\end{array}$} \\
\hline & \multicolumn{2}{|c|}{$\mathrm{K} 1 \mathrm{z}$} & \multicolumn{2}{|c|}{ Erkek } & \multicolumn{2}{|c|}{$\mathrm{K}_{1 \mathrm{Z}}$} & \multicolumn{2}{|c|}{ Erkek } \\
\hline & Yüzde & Frekans & Yüzde & Frekans & Yüzde & Frekans & Yüzde & Frekans \\
\hline Doğru & 56,27 & 704 & 54,88 & 899 & 74,50 & 932 & 60,62 & 993 \\
\hline Yanlış & 43,73 & 547 & 45,12 & 739 & 25,50 & 319 & 39,38 & 645 \\
\hline Toplam & 100 & 1251 & 100 & 1638 & 100 & 1251 & 100 & 1638 \\
\hline P değeri & \multicolumn{4}{|c|}{$0,02 *$} & \multicolumn{4}{|c|}{$0,01 * *$} \\
\hline
\end{tabular}

$* * *: p<0.001 * *: p<0.01 \quad *: p<0.05$ 
Tablo 6e. Cinsiyet ve Finansal Okuryazarlık İlişkisi

\begin{tabular}{|c|c|c|c|c|c|c|c|c|}
\hline \multirow{4}{*}{ Seçenekler } & \multicolumn{8}{|c|}{ GÜNLÜK BASİT HESAPLAMALAR } \\
\hline & \multicolumn{4}{|c|}{ Eğitim Öncesi } & \multicolumn{4}{|c|}{$\begin{array}{r}\text { Eğitim sonrası } \\
\end{array}$} \\
\hline & \multicolumn{2}{|c|}{$\mathrm{K} 1 \mathrm{Z}$} & \multicolumn{2}{|c|}{ Erkek } & \multicolumn{2}{|c|}{$\mathrm{K} 1 \mathrm{Z}$} & \multicolumn{2}{|c|}{ Erkek } \\
\hline & Yüzde & Frekans & Yüzde & Frekans & Yüzde & Frekans & Yüzde & Frekans \\
\hline Doğru & 38,84 & 216 & 39,83 & 290 & 75,00 & 417 & 62,36 & 454 \\
\hline Yanlış & 61,16 & 340 & 60,17 & 438 & 25,00 & 139 & 37,64 & 274 \\
\hline Toplam & 100 & 556 & 100 & 728 & 100 & 556 & 100 & 728 \\
\hline P değeri & \multicolumn{4}{|c|}{$0,05 *$} & \multicolumn{4}{|c|}{$0,003 * *$} \\
\hline
\end{tabular}

$* * *: p<0.001 \quad * *: p<0.01 \quad *: p<0.05$

\section{TARTIŞMA VE SONUÇ}

Bu araştırmanın temel çıkış noktası, Türkiye'de düşük olan tasarruf eğiliminin artırılabilmesi amacıyla ilk gençlik döneminde yer alan 12-14 yaş grubu öğrencilerin tasarruf bilincinin geliştirilmesine katk1 sağlamak için temel bir ekonomi bilgisini içeren finansal okuryazarlık eğitimi vermekti. Türkiye'de son y1llarda üretimdeki düşüşler, işsizlik oranı, enflasyon oranı ve dış borçlardaki artışlar nedeniyle ekonomik anlamda zor bir süreçten geçilmektedir. Bu sürecin rahatlatılmasında en önemli unsur üretken yatırımları artırmaktır. Ancak bunun için sermaye birikimi ve sermaye birikimi için ise tasarruf oranlarının artırılması gerekmektedir. Tasarruf oranının artması toplumda yer alan her bireyin bilinçli tüketimi, ihtiyaçlar ile istekleri doğru ayırt etmesi, biriktirdiği parayı bankacılık sistemi içerisine aktarmasının önemini kavraması ve rasyonel bir bütçe yapması ile doğru orantılıdır. Gençlerin belirtilen konularda doğru bir şekilde yönlendirilmelerinin ekonomiye ve sürdürülebilir kalkınmaya katkı yapması beklenmektedir.

Finansal eğitimin olası etkilerinin değerlendirildiği araştırmalara bakıldığında da finansal eğitimin bireyin ve toplumun genel tasarruf düzeyini artırdığı, finansal bilgi birikimi ile finansal davranışlar ve tercihler arasında anlamlı bir ilişkinin olduğu görülmüştür. Ancak bu tespitlere rağmen bu konuda verilmesi gereken eğitimin nitelikleri, uygulama alanları vb konularda üniversiteler açısından dikkate değer öneriler bulunmadığı gibi herhangi bir pratik uygulama da görülmemektedir. $\mathrm{Bu}$ araştırma projesinde yapılacak saha çalışmasının ve elde edilen sonuçların finansal okuryazarlık literatürüne de bu bakımlardan katkı sağlayacağı düşünülmüştür.

Araştırma süresi boyunca elde edilmek istenen bazı pratik sonuçlar vardır; bu ise gençlerin çalışma yaşamına atılmadan önce bütçeleme ve tasarruf etme, masraflarını ve borçlarını kontrol altına alma gibi konularda bilinçli olmalarını sağlayacak finansal eğitim programlarının oluşturulması ve uygulanmasıdır. Böylelikle, daha erken yaşlarda öğrenilen ve uygulanan finansal davranışlar daha kalıcı olarak yaşamın sonraki aşamalarında bireylerin finansal davranışlarının belirleyicisi olabilecektir. $\mathrm{Bu}$ ise bireysel ve toplumsal refahın artmasına, ülke ekonomisinin sağlıklı gelişmesine tabandan/temelden katkı sağlayacaktır.

Türkiye'nin genç nüfuslu bir ülke olması, ilk gençlik yıllarında finansal eğitimin önemini artırmaktadır. Teknolojiyi, yeni iletişim kanallarını ve günümüz ihtiyaçlarını en iyi bilen kitle gençlerdir. Onların finansal farkındalıklarının yüksek olması, tasarruf davranışlarına yansıyacak, böylece diğer yaş gruplarını ve hedef kitleleri de pozitif olarak etkileyecektir. Bu araştırmanın, üniversitelerin finans ve bankacılık bölümlerinin, toplumun her kesiminde yaygınlaştıracak finansal eğitim konusunda sorumluluk üstlenmeleri ile bu konuda da bir farkındalık oluşturması beklenmektedir. Böylelikle gençler ve toplumun diğer kesimlerinde finansal okuryazarlık düzeyi "çarpan etkisi" ile daha da yükselmiş olacaktır.

Yukarıda belirtilen amaç ve hedefler doğrultusunda, araştırma kapsamında örneklem olarak seçilen gruba finansal eğitim dersleri verilmiştir. Eğitimden beklenen sonuç, gençlerin temel ekonomi ve bankacılık bilgisi, faiz hesaplamaları vb. konularda bilgi düzeylerini artırmalarını sağlamak ve tasarruf davranışlarını olumlu yönde etkilemek olmuştur. Bu çerçevede değerlendirildiğinde istenen hedeflere büyük ölçüde ulaşıldığını söylemek mümkündür. 40 sorudan oluşan anket soruları öğrencilere hem eğitim öncesinde hem de eğitim sonrasında uygulanmış ve eğitim sonrasında temel bankacılık bilgisi konusunda gençlerin bilgi düzeyinin arttığı görülmüştür. Özellikle tasarruf edilen paranın yastık altında 
değil bankacılık sistemine yönlendirilmesinin ekonomiye sağlayacağı katkının kavranması bu projede önemsenen konulardan biridir. Gençlerin, küçük tasarruf sahiplerinin bankaya yatırdıkları paraların bankalar tarafından üretim yapacak işletmelere kredi olarak verilmesi ve böylelikle tasarrufların üretimde kullanılması mekanizmasını anlamaları finansal eğitim aracılığıyla sağlanmıştır. Bu anlayış, paranın ekonomik sistem içerinde yer almasının ekonominin, birey ve işletmelerin yararına olacağına vurgu yapması açısından önemlidir. Ayrıca para ve faiz ilişkisi de bu eğitimde ön plana çıkartılmış ve para ekonomisinde faizin varlık nedeni açıklanmıştır. Böylelikle, gençlerin ekonomide hem bankaların hem de faizin işlevini daha kolay kavramaları sağlanmıştır.

Diğer taraftan gençlerin vadesiz/vadeli mevduat, 18 yaş altı genç ve çocukların birimin yapmalarını teşvik edecek banka uygulamaları hakkında bilgi sahibi olmaları ve faizin nasıl hesaplandığı temel bilgisine ulaşmaları sağlanmıştır. Ancak bileşik faiz hesaplamalarında beklenen düzeyde yeterli bir kavrama olmadığı anket sonuçlarından görünmektedir. Ayrıca, Türkiye'de kredi kart kullanımının bilinçli bir şekilde yapılmaması nedeniyle erken yaşlarda bu konuda da bir farkındalık oluşturulmak istenmiştir. Gençlerin eğitim öncesinde de kredi kartı kullanımının bir borçlanma anlamına geldiğini ve kredi kartı harcamalarının gelirimiz ölçüsünde yapılması gerektiği temel bilgisine büyük oranda sahip oldukları görülmektedir.

Proje kapsamında yürütülen finansal eğitim süresince, gençlerin herhangi bir gelir veya kazançları olmamasına rağmen aile içinde yapabilecekleri tasarruflara ilişkin çok sayıda örnekler verilmiş, alışverişlerde malların fiyatlarını kıyaslama, bir malı satınalmadan önce onun istek mi yoksa ihtiyaç mı olduğu konusunda "10 saniye" kuralını uygulayabilme gibi örneklerle tasarruf bilinci bir miktar daha artırılabilmiştir. Bu konu paranın yönetimi konusunda bir farkındalık oluşturması açısından önemsenmiş ve nitekim anket sorularına verilen cevaplara bakıldığında bu yönde yine olumlu bir gelişme sağlanmıştır.

Paranın yönetimi ve tasarruf bilincinin geliştirilmesi için temel olan finansal okuryazarlığın ilk adımlarından biri de temel ekonomi bilgisine sahip olmaktır. Bu çerçevede, finansal eğitim süresince gençlere paranın tarihi, paranın ekonomideki rolü, ekonomide esas olan şeyin para değil üretim olduğu ve paranın sadece bir araç olduğu vurgulanmış ve paranın zaman değeri anlatılmıştır. Bu kapsamda enflasyon kavramının da bilinmesi ve enflasyon oranlarındaki yükselmenin paranın satın alma gücünü nasıl olumsuz etkilediğinin anlaşılması önemli olduğu için gençlere para, enflasyon, paranın zaman değeri gibi konular anlatılmış ve temel bir ekonomi bilgisi kazandırılmak istenmiştir. Bu konuda da istenen amaca büyük ölçüde ulaşıldığı anket sonuçlarından görülmüştür. Diğer taraftan, günlük hayatımızda sıklıkla karşılaştığımız basit hesaplamalara ilişkin örnekler çözülmüş ve öğrencilerin matematiksel işlem yapma becerileri artırılmıştır.

Finansal eğitim projesinin gençlere sağlayacağı yararın dışında, finansal okuryazarlık eğitimi ve bunun sonuçları ile ilgili olarak literatüre de bir katkı yapması beklenmektedir. Teorik olarak geniş bir literatüre sahip olan bu konunun, toplumsal bir dönüşümü hedeflemesi açısından pratikte de yaygınlaştırılmasının literatüre özgün bir katkı sunacağı düşünülmektedir. Finansal okuryazarlık değişkenlerinin cinsiyet, ailenin geliri ve eğitimi, öğrencilerin sayısal derslerdeki başarısı gibi değişkenlerle olan ilişkisi tespit edilmek istenmiş sadece cinsiyet değişkeninin anlamlı çıktığ 1 görülmüştür. Kız öğrenciler erkek öğrencilere göre tasarruf davranışı, temel ekonomi bilgisi, bankacılık bilgileri açısından finansal eğitim sonrasında erkek öğrencilere göre daha iyi bir performans göstermişlerdir. Aslında, teorik olarak ailenin gelir ve eğitiminin de finansal okuryazarlık seviyesi üzerinde etkili olduğu düşünülmekte ve araştırmalarda bu yönde bulgulara ulaşılmaktadır. Ailenin eğitim seviyesi arttıkça ya da gelir seviyesi yükseldikçe gençlerin daha iyi bir finansal okuryazarlık seviyesine sahip olacağı düşünülmektedir. Ancak bu araştırmada, bu ilişkiler istatistiksel olarak anlamlı çıkmamıştır. Ayvacık ilçesinde yaşayan ailelerin gelir seviyelerinin büyük oranda düşük olması ve benzer gelir gruplarına sahip olmaları ve eğitim seviyelerinin de genelde düşük olmasının bu sonucu ortaya çıkarmakta etkili olduğu düşünülmektedir.

Özet olarak araştırma ile ilgili genel bir değerlendirmek yapmak gerekirse; proje süresince uygulanan finansal eğitim ile hedeflenen amaçlara büyük oranda ulaşılmıştır. İlk olarak hedef kitle seçilen 12-14 yaş grubuna finansal okuryazarlık eğitimi verilmiş ve bunun olumlu yansımaları olduğu gözlemlenmiştir. İkinci olarak, Meslek Yüksekokulu öğrencilerinin bu projede eğitimci olarak yer

IBAD Sosyal Bilimler Dergisi / IBAD Journal of Social Sciences, (Özel Sayı/Special Issue), 2020 
almaları hem onların ekonomi bilgi düzeylerinin artmasına hem de finansal farkındalık düzeylerinin ve güvenlerinin artmasına katkı sağlamıştır. Son olarak Milli Eğitim okulları ve Üniversite arasında bir işbirliği oluşmuş ve bu tür etkinliklerin proje olmadan da sürdürülebileceği bir ortam yaratılmıştır. Bunun ise üniversitelerin toplumsal dönüşüme katkı sağmaları açısından son derece önemli olduğu düşünülmektedir.

Bilgilendirme / Acknowledgement:

Yazarlar aşağıdaki billgillendirmeleri yapmaktadırlar:

1- Araşıırmacıların katkı oranı eşittir.

2- Bu çalş̧ma "5th International Scientific Research E-Congress (IBAD - 2020)" adlı kongrede bildiri olarak 2 Eylül 2020 tarihinde sunulmuş sözlü bildirinin genişletilmiş halidir.

3- Bu çalışma, Çanakkale Onsekiz Mart Üniversitesi Bilimsel Araştırma Projeleri Koordinasyon Birimince, SBA-2019-3070 nolu proje olarak desteklenmiştir.

4- Makalenin yazarları arasında çıkar çatışması bulunmamaktadır.

5- Makalemizde etik kurulu izni Çanakkale Üniversitesi Sosyal Bilimler ve Eğitim Bilimleri Etik Kurulu 26.08.2019 tarih 6 nolu toplantı 2019/46 sayısı ile alınmıştır.

6- Bu makalede araştırma ve yayın etiğine uyulmuştur.

\section{KAYNAKÇA}

Alkaya, A. ve Yağlı, İ. (2015). Finansal okuryazarlık-finansal bilgi, davranış ve tutum: Nevşehir Hacı Bektaş Veli Üniversitesi İ̈BF öğrencileri üzerine bir uygulama. Uluslararası Sosyal Araştırmalar Dergisi, 8(40), 585-599.

Almenberg, J. ve Save-Söderberg J. (2011). Financial literacy and retirement planning in Sweden. CeRP Working Paper, No:112.

Atkinson, A. ve Messy, F. (2012). Measuring financial literacy: results of the OECD/International Network on Financial Education (INFE) pilot study. OECD Çalı̧̧ma Tebliğ̈i, No. 15. 15 Temmuz 2019 tarihinde http://dx.doi.org/10.1787/5k9csfs90fr4-en adresinden erişildi.

Bayram, S. S. (2015). Finansal okuryazarlık ve para yönetimi davranışları: Anadolu Üniversitesi öğrencileri üzerine uygulama. Uluslararası Işsletme ve Yönetim Dergisi, 2(2), 105-135.

Beal, D. J., ve Delpachitra, S. B. (2003). Financial literacy among Australian University students. Economic Papers, The Economic Society of Australia, 22(1), 65-78.

Chen, H. ve Volpe, R. P. (1998). An analysis of personal financial literacy among college students. Financial Services Review, 7(2), 107-128.

Cude, B., Lawrence, F., Lyons, A., Metzger, K., LeJeune, E., Marks, L., ve Machtmes, K. (2006). College students and financial literacy: what they know and what we need to learn. Proceedings of the Eastern Family Economics and Resource Management Association, 102-109.

Delavande, A., Rohwedder, S. ve Willis, R. (2008). Preparation for retirement, financial literacy and cognitive resources. Michigan Retirement Research Center Working Paper, No:190.

Er, B., Şahin, Y.E. ve Mutlu, M. (2017). Finansal eylem ve finansal okuryazarlık: üniversite öğrencilerine yönelik bir araştırma. Finans, Ekonomik ve Politik Yorumlar, 54(630), 75-88.

Goel, I. ve Khanna, S. Ram. (2013). Financial education as tool to achieve financial literacy. Eastern Economic Forum, 338-345.

Hastings, J.S., Madrian, B.C. ve Skimmyhom, W.L. (2012). Financial literacy, financial education and economic outcomes. National Bureau of Economic Research Çalışma Tebliği No. 18412. 
Hilgert, M. A., Hogarth, J. M., ve Beverly, S. G. (2003). Household financial management: the connection between knowledge and behavior. Federal Reserve Bulletin 89, 309-322.

Jappelli, T. ve Padula, M. (2011). Investment in financial literacy and saving decisions. CSEF Working Paper, No. 272.

Karataş, Ç. (2017). Finansal okuryazarlı̆̆ın geliştirilmesinde merkez bankalarının rolü ve Türkiye Cumhuriyet Merkez Bankası için bir değerlendirme. Merkez Bankası Uzmanlık Tezi, Ankara.

Kilıç, Y., Ata, H. ve Seyrek, İ. (2015). Finansal okuryazarlık: üniversite öğrencilerine yönelik bir araştırma. Muhasebe ve Finansman Dergisi, 66, 129- 150.

Kocabıyık, T. ve Teker, T. (2018). Finansal okuryazarlık: Süleyman Demirel Üniversitesi öğrencileri üzerine bir araştırma. SSAD Stratejik ve Sosyal Araştırmalar Dergisi,2(2), 117-144.

Krizek, J. T., Cems-Mim, L. L. M., ve Hradil, I. (2012). Standard in financial literacy for university students: methodology and empirical evidence. International Journal of Business and Social Research, 2(7), 21-32.

Lewis, S. ve Messy, F. (2012). Financial education, savings and investments: an overview. OECD Çalışma Tebliği No. 22.

Lusardi, A. (2008). Financial literacy: an essential tool for informed consumer choice? National Bureau of Economic Research Working Paper No.14084.

Lusardi, A. ve Tufano, P. (2009). Debt literacy, financial experiences, and overindebtedness. NBER Working Paper No: 14808.

Lusardi, A., Mitchell, O. S. ve Curto, V. (2010). Financial Literacy among the young. The Journal of Consumer Affairs, 44(2), 358-380.

Mandell, L. (2006). Financial literacy: if it's so important, why isn't it improving? Networks Financial Institute Policy Brief, (2006-PB), 08.

Mandell, L. ve Klein, L.S. (2007). Motivation and financial literacy. Financial Services Review, 16(2), 105-116.

Mandell, L. (2008). In overcoming the saving slump: how to increase the effectiveness of financial education and saving programs. ed. Annamaria Lusardi, 257-279. USA: University of Chicago Press.

Murphy, A.J. (2005). Money, money, money: an exploratory study on the financial knowledge of black college students. College Student Journal, 39(3), 478-488.

Nidar, S. R., ve Bestari, S. (2012). Personal financial literacy among university students (case study at Padjadjaran University students, Bandung, Indonesia). World Journal of Social Sciences, 2(4), 162-171.

Noctor, M., Stoney, S. ve Stradling, R.(1992). Financial literacy: a discussion of concepts and competences of financial literacy and opportunities for its Introduction into young people's learning, Report prepared for the National Westminster Bank. London: National Foundation for Education Research.

OECD. (2005). Improving financial literacy analysis of issues and policies. Paris: OECD Publishing.

OECD. (2008). OECD Journal: General papers, special issue: Financial education, 2008/3. Paris: OECD Publishing.

OECD. (2014). Financial education for youth: The Role of schools. Paris: OECD Publishing.

OECD. (2016). OECD/INFE international survey of adult financial literacy competencies. Paris: OECD Publishing. 
Sabri, M. F. ve MacDonald, M. (2010). Savings behaviour and financial problems among college students: the role of financial literacy Malaysia. Cross-Cultural Communication, 6(3),103-110.

Sarıül, H. (2014). A survey of financial literacy among university students. Muhasebe ve Finansman Dergisi, Ekim, 207-224.

Sekita, S. (2011). Financial literacy and retirement planning in Japan. Journal of Pension Economics and Finance, 10(4), 637-656.

Sezer, D. Ve Gümüş, U.T. (2016). Finansal okuryazarlık düzeyinin belirlenmesi: üniversite öğrencileri üzerine bir araştırma. Kara Harp Okulu Bilim Dergisi, 26(2), 1-37.

SPK. (2012). Türkiye finansal yeterlilik araştırması sonuç raporu. 27 Mayıs 2020 tarihinde https://www.spk.gov.tr/Duyuru/Dosya/20121116/0 adresinden erişildi.

Şahin, C. (2014). Bir meslek yüksekokulu öğrencilerinin finansal okuryazarlık düzeyinin belirlenmesine ilişkin bir araştırma: Bozüyük meslek yüksekokulu örneği. Uluslararası Hakemli Ekonomi Yönetimi Araştırmaları Dergisi, 2(1), 19-29.

Şamiloğlu, F., Kahraman, Y. E. ve Bağcı, H. (2016). Finansal okuryazarlık araştırması: Erciyes Üniversitesi öğrencileri üzerinde bir uygulama. Uluslararası Yönetim İktisat ve Isşletme Dergisi, ICAFR 16 Özel Sayısl, 308-318.

Tuna, G. ve Ulu, M.O. (2016). Üniversite öğrencilerinin finansal okuryazarlık düzeylerini etkileyen faktörlerin belirlenmesi: işletme bölümü öğrencileri üzerine bir araştırma. Uluslararası Yönetim İktisat ve İsletme Dergisi, ICAFR 16 Özel Sayısı, 128-141.

Wagland, S. P. ve S. Taylor (2009).When it comes to financial literacy, is gender really an issue? Australasian Accounting Business and Finance Journal, 3(1), 13-25.

Worthington, A. C. (2006). Predicting financial literacy in Australia. Financial Services Review, 15(1), 59-79. 